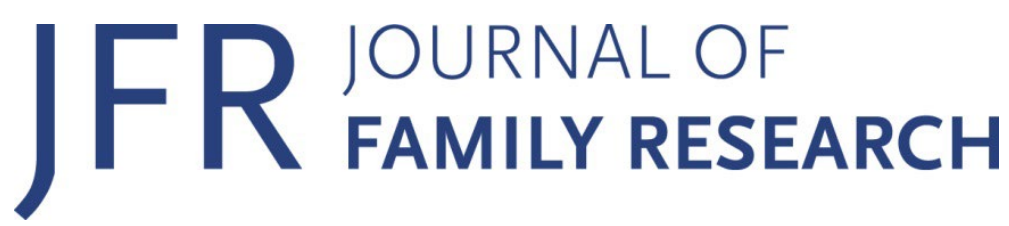

\section{Childcare and housework during the first lockdown in Austria: Traditional division or new roles?}

\author{
Caroline Berghammer ${ }^{1,2}$ \\ ${ }^{1}$ University of Vienna, Department of Sociology, ${ }^{2}$ Vienna Institute of Demography, \\ Austrian Academy of Sciences, Wittgenstein Centre for Demography and Global Human \\ Capital (IIASA, OeAW, University of Vienna)
}

Address correspondence to: Caroline Berghammer, University of Vienna, Department of Sociology, Rooseveltplatz 2, 1090 Vienna (Austria).

Email: caroline.berghammer@univie.ac.at

\begin{abstract}
Objective: This study analyses how much time mothers and fathers spent on childcare and housework during and after the first COVID-19 lockdown in Austria (starting in mid-March 2020) and how they distributed that time between themselves.

Background: Parents needed to reallocate care work between themselves as, on the one hand, kindergartens and schools closed for two months and, on the other hand, employment-related changes arose, e.g., working from home. The results are discussed in light of major theories that address the division of care work: the time availability approach and gender role theory.

Method: This study employs data from the Austrian Corona Panel Project 2020/21, a webbased survey using quota sampling, which started in the second week of the first lockdown $(\mathrm{n}=372$ for respondents in couples with children below age 15). Altogether, seven waves contain information about time spent on childcare and housework; three were conducted during or right after the first lockdown (April and May 2020) and four between June 2020 and February 2021. Linear and logistic regression models were used.

Results: Within the whole study period, parents' total workload (care work and employment) was highest during the first lockdown. The workload was greatest-an average of 15 hours on weekdays - among mothers with children below age six. While mothers shouldered more care work in most families, partners shared tasks equally in around one third of them. Care time depended on employment hours, especially for fathers. Yet, it was higher for mothers with the same level of employment as fathers.

Conclusion: The COVID-19-related employment changes led to a rise in arrangements that rarely existed before in Austria, e.g., fathers working part-time. Consequently, some fathers took on new roles, especially when they worked from home (mostly among the higher educated), were non-employed (mostly among the lower educated) or worked part-time. The paper concludes by discussing whether those experiences may permanently result in more egalitarian gender roles.
\end{abstract}

Key words: Austria; childcare; housework; lockdown; time use

doi: $10.20377 /$ jrr-701 


\section{Introduction}

The restrictions related to the COVID-19 pandemic led to sweeping changes in families' everyday lives in Austria. During the first lockdown that began in mid-March 2020, ${ }^{1}$ kindergartens and schools closed for two months. ${ }^{2}$ Furthermore, authorities advised against meeting friends or relatives not living in the same household, which meant that, e.g., grandparents, babysitters, and housekeepers were supposed to avoid supporting families with care work (childcare and housework). This created the unique situation where childcare and schooling were almost entirely moved from institutions and informal caregivers to families, leaving families quite isolated. Hence, parents' care time, especially childcare time, skyrocketed during the lockdown.

The lockdown also had manifold consequences for employment, including increases in working from home, rising unemployment, and reduced work hours. Employees with essential jobs in areas like health or (some parts of) the retail sector generally continued to work on-site, with women working in these jobs more often than men (Bock-Schappelwein \& Mayrhuber 2020). At the same time, authorities advised the public to work from home whenever feasible. The share of employees working from home increased sharply, reaching an estimated approx. 35\% during the first lockdown (Pichler, Schmidt-Dengler, \& Zulehner 2020; Statistics Austria 2020b). Throughout this period, restaurants, hotels, and most shops (except for, e.g., groceries, pharmacies) closed and the Austrian unemployment rate soared. By the end of April 2020, the unemployment rate (national definition) was 13\%, compared to 7\% in April 2019 (Statistics Austria 2020c). To prevent unemployment from continuing to rise, the government financially supported work time reductions (short-time employment; Kurzarbeit in German). Industry sector and level of education played a large role in determining how strongly employees were affected by short-time unemployment, unemployment, and working from home. Working from home was much more common among highly educated persons, while short-time employment and unemployment disproportionally affected their lower educated peers (see table 1; Pichler, Schmidt-Dengler, \& Zulehner 2020), which saw the latter increase greater mental health risks than other members of the working population (OECD 2021).

These changes to care work and employment meant that couples needed to renegotiate and redistribute work between themselves within a very short time, which affected the gender balance. Moreover, in many couples, these changes led to work-family conflicts (e.g. Berghammer 2020b; Zartler et al. 2021) and compromised partnership quality

1 The first lockdown started on 16 March 2020 and ended with the curfew being lifted on 1 May 2020. However, restrictions were gradually reduced from mid-April onwards (Pollak, Kowarz, \& Partheymüller 2020), for instance, small shops reopened on 14 April. Other restrictions lasted beyond lifting the curfew: Restaurants reopened on 15 May. Kindergartens and schools generally reopened from 18 May onward; schools reopened according to a split-shift schedule: Half of children attended school on two/three days per week and the other half on the remaining two/three days (Blum \& Dobrotić 2021). There were some exceptions: Kindergartens in Vienna reopened on 4 May, as well as classes for students in their final year of upper-secondary school, while all other upper-secondary school students continued to receive instruction through distance learning until the end of the school year.

2 Parents who worked in essential jobs could send their children to kindergartens and schools, but only 1-2\% attended (Blum \& Dobrotić 2021). 
(Berghammer \& Beham-Rabanser 2020) and, in turn, had consequences for psychological well-being (Pieh, Budimir, \& Probst 2020; Rodrigues et al. 2021). Against this background, this study first explores the magnitude of mothers' and fathers' childcare and housework time between April 2020 and February 2021, focusing on the first lockdown and the period immediately thereafter (April and May 2020). It investigates how the magnitude depended on family characteristics (age of the youngest child and number of children), level of education, and employment characteristics (work hours, working from home). Second, this study analyses the distribution of childcare and housework within couples (based on respondents' assessment of their partner's care hours), again paying close attention to family characteristics and couples' employment arrangements. The study's focus is on couples with children below age 15 , because this group faced the greatest increase in care work by far (Berghammer 2020a; Six et al. 2020). It employs data from the Austrian Corona Panel Project (ACPP), a web-based survey of around 1,500 respondents using quota sampling, which was launched in the second week of the first lockdown (Kittel et al. 2020, 2021). Because no comparable data from the period before are available, this study cannot address whether or not the pandemic led to a more unequal division of care work. Seven ACPP waves from between April 2020 and February 2021 contain information on childcare and housework (five of which concern couples). The descriptive analyses consider all seven waves, while the multivariate analyses focus on the period when kindergartens and schools closed, using the three waves from April and May 2020. This allows for both a broad overview of parents' workloads during the different phases of the COVID-19 pandemic and a close examination of the most severe and disruptive period in the first lockdown.

\section{Employment and care work in Austria during the first lockdown}

Austria has high labour force participation rates both for men (92\%) and women (86\%) (age group 25-54 in 2019; Eurostat database 2020) and one of the lowest unemployment levels in Europe. Austria is consistently classified as a conservative welfare state (Bambra 2007), with care work being allocated more to families (predominantly mothers) and less to childcare institutions. Consequently, it is a country with strong "child effects" for mothers in terms of working hours and earnings (Kleven et al. 2019; Steiber, Berghammer, \& Haas 2016). The female part-time employment rate is the highest in Europe after the Netherlands and Switzerland. ${ }^{3}$ In 2019, around half of all Austrian couples with children below age 15 lived according to a male full-time/female part-time model (46\%) while $28 \%{ }^{4}$ of couples lived according to the male breadwinner model (Statistics Austria 2020e). The remaining quarter consisted of couples where both parties were employed full-time or in other arrangements. While mothers and fathers in Austria had a fairly equal total workload from employment and care work (and fathers with children below age six had a higher workload),

3 The part-time rate was $47.3 \%$ among women and 9.5\% among men in Austria in 2019; it was 73.6\% among mothers and 5.8\% among fathers with children below age 15 (Statistics Austria 2020d).

4 Includes parents on parental leave, whereby it was assumed that $90 \%$ of them are women. 
the division of paid and unpaid work was quite unbalanced (Wernhart et al. 2018). ${ }^{5}$ This was the situation in which the COVID-19 pandemic hit. The remainder of this section first describes the ensuing employment changes by gender and education, and then reviews studies that addressed care work during the pandemic.

During the first lockdown, holding an essential job that secured, for instance, the supply of food, transportation, energy, telecommunication, social, and health services, was one of the few reasons for which people could leave the home. Women were more frequently employed in such occupations, yet they were also overrepresented in areas that had to close like the retail (except for, e.g., supermarkets, pharmacies), gastronomy, culture, and beauty sectors (Bock-Schappelwein \& Mayrhuber 2020). Authorities recommended working from home whenever possible, and its prevalence was similar among men and women (see table 1 ). It was most suitable for non-manual occupations without regular customer contact (Bock-Schappelwein 2020). Consequently, there were stark differences depending on level of education: $75 \%$ of highly educated employees predominantly worked from home in April 2020 compared to $40 \%$ of those with a medium education and only $19 \%$ of those with a low education (see table 1; educational categories were defined to correspond to those used in this study). While working from home was implemented suddenly at the lockdown's onset (leaving many employees unprepared due to a lack of immediate resources), working hour reductions were more gradual. Starting in mid-March 2020, companies could apply for short-time employment (and retroactively to the beginning of March). Over the course of the first lockdown, employees were increasingly registered for short-time employment. When employers joined this programme, their employees had their working hours substantially reduced, but continued to earn 80 to $90 \%$ of their former wage. As table 1 depicts, more than $20 \%$ of employees in Austria were officially registered for short-time employment in April 2020, with shares being similar among men and women (Steiber, Siegert, \& Vogtenhuber 2021 in this Special Issue). ${ }^{6}$ Short-time employment was used more frequently by low educated employees (24\%), compared to medium (19\%) and highly educated (15\%) employees. However, the data also show that a much higher share of close to $40 \%$ actually worked fewer hours regardless of if they were officially registered for shorttime employment. The shares were similar among men and women and by level of education. Those reductions in working time represented an important shift for men: While part-time employment was almost exclusively used by mothers and rarely by fathers before the pandemic (only $6 \%$ of fathers with children below age 15 worked part-time compared to $74 \%$ of mothers; see footnote 3), COVID-19-related employment changes prompted a novel situation where significant shares of men also experienced a decline in working hours. Almost $10 \%$ of employees, however, reported working more hours compared to the period before the lockdown, especially the higher educated. Finally, the unemployment rate rose steeply during the lockdown in Austria. Unemployment initially had a stronger effect on men (partly because construction sites were closed), until women caught up in April (Bock-Schappelwein \& Mayrhuber 2020). Moreover, the widely recognised negative education gradient in unemployment became steeper during the COVID-19 pandemic,

5 The data used by Wernhart and colleagues pertain to 2008/09, which was the last time a diary-based time use survey was conducted in Austria (Statistics Austria 2009).

6 According to register data, 31\% of men and 27\% of women worked in short-time employment in April 2020 among those employed (excludes self-employed; Vogtenhuber \& Steiber 2021). 
since low educated persons experienced the most consequences (Bock-Schappelwein, Famira-Mühlberger, \& Mayrhuber 2020). The high prevalence of short-time employment and unemployment visibly affected the financial well-being of families: About one third of couple families with minor children reported a decline in their household income (Steiber, Siegert, \& Vogtenhuber 2021 in this Special Issue). Overall, the rise in working from home, short-time employment, and unemployment led to new constellations in couples. While the father full-time/mother part-time model dominated before the pandemic, arrangements became more diverse during the first lockdown. This included more gender egalitarian models or even role reversals. For instance, some fathers worked in short-time employment at home while mothers continued to work (full-time) on-site at essential jobs.

Table 1: Employment characteristics by gender and level of education (in \%), April and May 2020

\begin{tabular}{lrrrrrrrr}
\hline & $\begin{array}{l}\text { Working from } \\
\text { home } \\
(1)\end{array}$ & $\begin{array}{l}\text { Short-time } \\
\text { employment } \\
(2)\end{array}$ & \multicolumn{2}{l}{$\begin{array}{l}\text { Working } \\
\text { fewer hours } \\
(3)\end{array}$} & \multicolumn{2}{l}{$\begin{array}{l}\text { Working } \\
\text { more hours } \\
(4)\end{array}$} \\
\hline & April & May & April & May & April & May & April & May \\
\hline Men & 37 & 29 & 22 & 26 & 36 & 27 & 8 & 9 \\
Women & 40 & 24 & 19 & 18 & 38 & 25 & 10 & 8 \\
Low education & 19 & 14 & 24 & 23 & 36 & 23 & 7 & 7 \\
Medium education & 40 & 30 & 19 & 26 & 31 & 31 & 9 & 11 \\
High education & 75 & 45 & 15 & 18 & 40 & 26 & 11 & 10 \\
\hline Total & 38 & 27 & 21 & 22 & 37 & 26 & 8 & 9 \\
\hline
\end{tabular}

Source: COVID-19 Prevalence Study (surveys conducted by Statistics Austria from 16 to 24 April and from 18 to 27 May 2020) (Statistics Austria 2020a)

Notes: Definition of education levels: Low: Complete or incomplete primary education; apprenticeship (vocational school); intermediate vocational education school; Medium: Higher vocational or academic school with university entrance qualification (in Austria, the Matura); High: University; university of applied sciences; post-secondary and short-cycle tertiary education (BHS-Abiturientenlehrgang, Kolleg, Hochschulverwandte Lehranstalt, Universitätslehrgänge). (1) Working predominantly from home among those employed, (2) Registered for shorttime employment among those employed, (3) and (4) Working fewer/more hours compared to the week before the lockdown ( 9 to $15 \mathrm{March}$ ) among those employed.

During the first lockdown, parents in Austria experienced a strong rise in care work: $74 \%$ of mothers and $66 \%$ of fathers reported spending much more or somewhat more time on childcare compared to the period before the lockdown (Berghammer 2020a). Combining this elevated level of childcare with employment was often very challenging (e.g. BehamRabanser et al. forthcoming; Zartler et al. 2021). Parents who worked from home had to engage in employment while their children were present and in need of care and/or support with distance learning. Mothers were more likely than fathers to report that their children remained in the same room as them while working from home (Derndorfer et al. 2021). This was an unprecedented situation that was especially detrimental to the work-life balance of parents with young children and those living in crowded housing (Berghammer 2020b). 
These parents often reported being unable to concentrate well on their paid work or having insufficient time for their tasks. These difficulties led many parents to use vacation days, compensatory time, or other kinds of leave in order to meet their increased childcare demands. Hence, some parents were concerned about not having any remaining vacation days for childcare or recreation during the summer (Kittel, Pollak, \& Partheymüller 2020). Parents also resorted to working evenings and nights, as well as over the weekend (Schönherr 2020). Short-time employment and "informal" reductions in employment hours also allowed parents to better combine their jobs with the abrupt increase to childcare demands.

Many scholars have focused on how the distribution of care work changed before and after the onset of the COVID-19 pandemic. Unfortunately, this question cannot be addressed for Austria, because no comparable data from the period leading up to the pandemic are available (for details, see section 4.1. on data). Studies have been conducted on several European countries including the United Kingdom (Zamberlan, Gioachin, \& Gritti 2021), the Netherlands (Yerkes et al. 2020), Italy (Del Boca et al. 2020) and Spain (Farre et al. 2020), as well as the United States (e.g. Alon et al. 2020). The studies generally asked (e.g. Hipp \& Bünning 2020): Have mothers shouldered the additional care work and has the distribution consequently become more unequal? Conversely, have mothers and fathers shared the additional care work, leading to a more balanced distribution? Since the country shares many institutional and cultural similarities with Austria, including a high share of mothers who work part-time, empirical studies from Germany provide useful insights. ${ }^{7}$ Using the German Socio-Economic Panel, Kreyenfeld and Zinn traced changes in childcare time between 2019 and spring 2020 (during lockdown) among mothers and fathers in couples with children up to age 11 (Kreyenfeld \& Zinn 2021). They showed that mothers' childcare time increased by 2.9 hours per weekday (from 6.7 to 9.6 hours) and that fathers' childcare time increased by 2.5 hours (from 2.8 to 5.3 hours). Hence, the absolute increase was (slightly) sharper among mothers, while the relative increase was significantly stronger among fathers. In other words, mothers and fathers shared the additional childcare time. The study also revealed that childcare time increase was greatest among low and medium educated fathers because their higher levels of short-time employment or unemployed meant they had more time at their disposal. During the lockdown, low educated fathers spent 6.4 hours on childcare, compared to 6.0 and 4.2 hours for medium and highly educated fathers, respectively. Additionally, Hank and Steinbach focused on the distribution within couples in Germany and showed that women's share in childcare time increased in $24 \%$ of couples, decreased in $20 \%$, and was stable in the remaining $56 \%$; for housework, it decreased in 20\% and increased in another 20\% (Hank \& Steinbach 2021). This finding reaffirms that mothers and fathers shared the additional childcare time. The authors also showed that extremes became more frequent in that " $[\mathrm{m}]$ ore women have taken on the primary or almost exclusive responsibility for housework and childcare, but - at the same time - more men are now contributing at least equally to these tasks" (Hank \& Steinbach 2021: 107).

7 However, fewer employees worked from home during the lockdown in Germany than in Austria in April 2020 (23\% in Germany; Bujard et al. 2020) and fewer were in short-time employment (18\% in Germany; Bundesagentur für Arbeit 2021). 


\section{Theoretical framework and hypotheses}

This study rests upon two main theoretical frameworks that are frequently used to explain the unequal distribution of paid and unpaid work between men and women: the time availability approach and gender role theory (Geist \& Ruppanner 2018). ${ }^{8}$ The time availability approach expects that the amount of unpaid work is largely determined by available time, and that available time is largely determined by the amount of paid work. There is empirical support for this perspective from different countries. For instance, reallocating housework to the unemployed spouse (Fauser 2019; Gough \& Killewald 2011) or fathers with part-time employment doing more care work until they started working full-time (Bünning 2020). However, the workplace itself also matters: During the pandemic, parents who worked from home while their children were present might have invested more time caring than their peers who worked at their regular worksites. There was strong, ongoing institutional pressure regarding the amount and place of employment (Geist \& Ruppanner 2018), e.g., which occupations were defined as essential, who lost their jobs, who was able and allowed to work from home, ${ }^{9}$ whose employer used short-time employment, as well as whose work tasks could be shifted to evenings, nights, and weekends. Childcare infrastructure also posed institutional constraints (e.g., how well prepared they were to care for children during the lockdowns, how well distance learning worked), which shaped families' available time and how they subsequently negotiated and made choices regarding care time. The time availability approach is gender-neutral and expects symmetrical amounts of unpaid work from mothers and fathers given the same time resources. Based on this approach, the first hypothesis is formulated as follows: During the first lockdown, non-employed parents spent the most time on care, followed by those working part-time, and then full-time working (H1a). Parents who worked from home performed more care work than their peers who worked on-site (H1b).

The time availability approach is complemented by gender role theory, which enables gender-specific predictions and explains why people often behave according to gendertypical roles (e.g. Eagly \& Wood 2016). Traditional gender roles link femininity to mothers as carers and masculinity to the fathers' provider status as breadwinner. By European standards, traditional gender roles are fairly dominant in Austria (Steiber \& Haas 2010). For mothers, being employed while having children below age three is often disapproved of, as is full-time employment even after children enter school. For example, in 2018, only $25 \%$ of respondents (strongly) approved of mothers with children below the age of three holding a full-time job, while twice as many-49\%-(strongly) disapproved (European Social Survey 2018; 26\% neither approved nor disapproved). Correspondingly, mothers are usually the secondary earners and the primary childcare providers, making them more experienced in balancing those multiple roles. They are also expected to adjust their (more limited) employment to acute family needs, such as caring for a sick child (Maume 2008 for the United States). For these reasons, it may have seemed evident for families to shift additional

8 Exchange/bargaining theory, another prominent framework in this field, assumes that partners' resources grant decision making power. Resources are mostly measured by partners' (relative) incomes. The dataset does not contain such information, which prevents empirically addressing this characteristic.

9 A German study showed that the share of people working from home was similar among persons without (25\%) and with (29\%) children in March 2020, which is indicative of constraints (Möhring et al. 2020). 
care work to mothers. There is empirical evidence of a (somewhat) stronger increase among mothers for several countries (e.g. Del Boca et al. 2020; Farre et al. 2020; Kreyenfeld \& Zinn 2021). Therefore, considering available time, the second hypothesis is stated as follows: At a similar level of employment, mothers performed more care work than fathers (H2).

Gender attitudes and care time both vary by educational level (and other socio-economic characteristics). Highly educated parents generally spend more time on childcare (Dotti Sani \& Treas 2016) and hold more egalitarian gender role attitudes (Steiber, Berghammer, $\&$ Haas 2016) than their lower educated peers. Employment changes during the COVID-19 pandemic were strongly stratified by educational level, with higher educated employees working much more often from home, while unemployment or short-time employment were more common for the lower educated; however, level of education mattered only little for actual working time reductions (see table 1). Thus, the third hypothesis proposes that higher educated parents spent more time on care than their lower educated peers $(\mathrm{H} 3)$.

Finally, this study pays attention to the different types of care work, i.e., childcare and housework. Childcare is usually perceived as more rewarding and pleasurable than housework (Geist \& Ruppanner 2018). During the first lockdown in Austria, childcare time rose more sharply than housework time (Berghammer 2020a). It seems reasonable that unfocused, supervisory childcare time increased more strongly than active childcare, especially among parents who worked from home while caring for their children. Certain activities probably became more time-consuming (e.g., playing, learning with children), while the time required for others remained stable (e.g., physical care). Generally speaking, playing is the task that fathers share most equally with mothers (Statistics Austria 2009). Empirical evidence about the distribution of childcare versus housework during the pandemic as well as changes compared to before its onset is mixed (Del Boca et al. 2020; Farre et al. 2020; Hank \& Steinbach 2021). Before the pandemic, childcare was shared more equally than housework among couples in Germany (Hank \& Steinbach 2021), but similarly in Spain (Farre et al. 2020). Changes compared to before the pandemic were either similar for both types (Farre et al. 2020), or childcare was shifted more towards mothers than housework, resulting in housework being shared slightly more equally (Hank \& Steinbach 2021; Yerkes et al. 2020). Hence, there are two alternative hypotheses concerning the period of the first lockdown: Housework time was shared more equally between partners than childcare time (H4a); both housework time and childcare time were shared equally $(\mathrm{H} 4 \mathrm{~b})$.

\section{Data, measures and, methods}

\subsection{Data}

This study is based on data from the Austrian Corona Panel Project (ACPP; version 3), a survey of around 1,500 respondents that was launched in the second week of the first lockdown (27 to 30 March 2020) (Kittel et al. 2020, 2021). It was repeated each week until the end of May, then bi-weekly and, from July onwards, once per month. The study is currently still ongoing (see https://viecer.univie.ac.at/coronapanel/). It was constructed and 
commissioned by an interdisciplinary team at the University of Vienna. ${ }^{10}$ The ACPP interviews were conducted online and took approximately 20 minutes. The respondents were sampled from a pre-existing online access panel based on several key demographics (age, gender, region, municipality size, and educational level) to mirror the distribution of the Austrian resident population (quota sampling). The initial participation rate was 35\%; panel mortality occurred, and new respondents replaced those that dropped out to achieve a stable sample size. Retention rates are given in table 2.

The ACPP survey consists of a core module that was repeated in each wave, and rotating modules that covered other diverse topics. The core module contains a large number of socio-demographic and socio-economic questions, including detailed information on working status (e.g., work hours, working from home). Rotating modules in seven waves included questions on the number of hours and minutes spent on a typical weekday for (child)care and housework (waves 2, 5, 8, 11, 14, 17, and 20). Table 2 provides detailed information on these waves. Waves 2 and 5 were conducted during the first lockdown (which ended on 30 April), while wave 8 coincided with less-restricted circumstances, but took place at a time where kindergartens and schools were still closed. ${ }^{11}$ During wave 11, which took place in mid-June, primary and lower secondary schools operated on a splitshift-schedule, where half of the class attended school on two/three days per week and the other half on the remaining two/three days (Blum \& Dobrotić 2021); on their days at home, children were enrolled in distance learning. Afterschool activities were cancelled, and grandparents (and other carers from outside the household) were discouraged from helping out due to health risks. Families or individual members were sometimes quarantinedeither when they contracted COVID-19 themselves or were in contact with persons who did. Wave 14 was conducted during the summer holiday season in mid-August, which was marked by lower incidence rates and less measures. However, travel restrictions led many people to spend their vacations in Austria. Wave 17 was conducted during the second lockdown, which started on 3 November as a "light lockdown" and was extended on 17 November as a "hard lockdown" that included the closure of kindergartens, primary, and lower secondary schools. This time, however, kindergartens and schools were open for parents in urgent need of childcare, during which in mid-November around 15\% of children attended school on-site and around three times as many attended kindergarten on-site (Der Standard 2021). Because the survey questions are worded retrospectively (asking about the previous week), wave 17 captures the week just before the kindergarten and school closures. Finally, wave 20 coincides with the semester break in Western Austria and Burgenland in February 2021, and a period of kindergarten and school closures in Eastern Austria (but one with more children attending on-site).

The analytical sample includes respondents in couples ${ }^{12}$ between the ages of 20 and 59 years with children below age 15 . Each wave contains around 240 cases; $24 \%$ of respondents

10 The principal investigators are Bernhard Kittel (Department of Economic Sociology), Sylvia Kritzinger (Department of Government), Hajo Boomgaarden (Department of Communication), and Barbara Prainsack (Department of Political Science).

11 More precisely, kindergartens and schools reopened on 18 May (for details, see footnote 1) during the fieldwork period of wave 8, but the questions on care time refer to the week before (see section 4.2.).

12 Respondents were excluded who reported not living with a partner in more than one wave in order to exclude turbulent partnership constellations (6.5\%). 
participated in all seven waves, $20 \%$ in one or two waves, and the rest in three to six waves. There are 372 respondents after pooling all seven waves. The low case numbers prevented studying changes at the individual level. The data do not allow distinguishing between biological and non-biological children. For brevity, the terms "mothers" and "fathers" are used in the results, although some adults (in particular, fathers) might be stepparents rather than biological parents.

The ACPP data offers several advantages. First, quota sampling is preferable to the adhoc samples that were frequently collected in other studies during this period. Second, the survey was already launched by the second week of the lockdown and contains time-use measures in multiple waves, which facilitates studying trends over the course of the lockdown and beyond. Third, in addition to containing respondents' estimates of their own care time, wave 8 onward also addresses their partners' care time. The dataset is limited by the low case numbers for couples with children and by some variables (working from home and level of education) being unavailable for the partner. Moreover, the partner's care time is less reliable because it is estimated by the respondent instead of being self-reported by the partner. ${ }^{13}$ Questions on care time have unfortunately not been posed during the second lockdown (school and kindergarten closures in late November and December 2020), preventing a comparison with the first lockdown.

It would have been preferable to compare care time during the lockdown with care time before this period. However, previous surveys about Austria that used similar retrospective measures of care time asked for hours per week, ${ }^{14}$ whereas the ACPP survey asked for hours per weekday. Thus, the different surveys are not comparable, especially since fathers perform a disproportionate share of childcare on weekends.

13 This issue may have been less problematic during the pandemic, since partners probably negotiated the division of care time more explicitly and both partners were often at home and thus aware of each other's time use.

14 The European Quality of Life Surveys 2007, 2012, and 2016 collected information on respondents' weekly childcare and housework time (and per day in 2003). The European Social Survey 2010 contained measures about respondents' and partners' weekly housework time and the ISSP 2012 measured respondents' and partners' weekly housework time and time spent caring for family members (more general than childcare). 
Table 2: ACPP survey wave characteristics

\begin{tabular}{|c|c|c|c|c|c|c|}
\hline \multicolumn{2}{|c|}{ Period characteristics } & \multirow{2}{*}{$\begin{array}{l}\text { Wave } \\
2 \\
2\end{array}$} & \multirow{2}{*}{$\begin{array}{l}\begin{array}{l}\text { Fieldwork } \\
\text { period }\end{array} \\
\begin{array}{l}\text { 3-8 April } \\
2020\end{array} \\
\end{array}$} & \multirow{2}{*}{$\begin{array}{r}\begin{array}{l}\text { Total number } \\
\text { of } \\
\text { respondents }\end{array} \\
1559\end{array}$} & \multirow{2}{*}{$\begin{array}{l}\begin{array}{l}\text { Retention } \\
\text { rates } \\
\text { (share of } \\
\text { first wave) }\end{array} \\
86 \%\end{array}$} & \multirow{2}{*}{$\begin{array}{l}\begin{array}{l}\text { Analytical sample } \\
\text { (respondents in } \\
\text { couples with } \\
\text { children }<15 \text { years) }\end{array} \\
222\end{array}$} \\
\hline \multirow{5}{*}{$\begin{array}{l}1^{\text {st }} \\
\text { lockdown }\end{array}$} & \multirow{3}{*}{$\begin{array}{l}\text { School and } \\
\text { kindergarten } \\
\text { closures }\end{array}$} & & & & & \\
\hline & & 5 & $\begin{array}{l}\text { 24-29 April } \\
2020\end{array}$ & 1515 & $74 \%$ & 245 \\
\hline & & 8 & $\begin{array}{l}\text { 15-20 May } \\
2020\end{array}$ & 1501 & $69 \%$ & 253 \\
\hline & $\begin{array}{l}\text { Schools in split- } \\
\text { shift schedule }\end{array}$ & 11 & $\begin{array}{l}\text { 12-17 June } \\
2020\end{array}$ & 1510 & $66 \%$ & 250 \\
\hline & $\begin{array}{l}\text { Holiday period, } \\
\text { less restrictions }\end{array}$ & 14 & $\begin{array}{l}14-19 \\
\text { August } \\
2020\end{array}$ & 1540 & $56 \%$ & 239 \\
\hline \multirow[t]{2}{*}{$\begin{array}{l}2^{\text {nd }} \\
\text { lockdown } \\
\text { ("light”) }\end{array}$} & $\begin{array}{l}\text { Week before } \\
\text { school and } \\
\text { kindergarten } \\
\text { closures }\end{array}$ & 17 & $\begin{array}{l}13-20 \\
\text { November } \\
2020\end{array}$ & 1592 & $60 \%$ & 237 \\
\hline & $\begin{array}{l}\text { Holidays or } \\
\text { school and } \\
\text { kindergarten } \\
\text { closures }\end{array}$ & 20 & $\begin{array}{l}12-19 \\
\text { February } \\
2021\end{array}$ & 1574 & $58 \%$ & 225 \\
\hline
\end{tabular}

Source: Austrian Corona Panel Project 2020/21: Method report (https://viecer.univie.ac.at/coronapanel/austriancorona-panel-data/method-report/)

\subsection{Measures}

The main dependent variables are hours per working day ${ }^{15}$ spent on childcare and housework. The question was worded as (emphasis in original): "Think about a typical working day during the last week. Please indicate how much time (in minutes or hours) you spent on the following activities." 16 This was followed by a list of nine items including (a) housework/shopping and (b) care/childcare. Moreover, questions from wave 8 onward also asked about the number of hours and minutes spent on these tasks by the partner. This question was worded as (emphasis in original): "Think about a typical working day during the last week. Please indicate how much time (in minutes or hours) your partner spent on

15 The definition of a working day is not consistent in Austrian law and either includes or excludes Saturday. For simplicity, this study instead refers to "weekday."

16 Original German wording: "Denken Sie an einen typischen Werktag in der letzten Woche. Bitte geben Sie an, wie viel Zeit (in Minuten oder Stunden) Sie mit folgenden Tätigkeiten verbracht haben." Hausarbeit/Einkaufen; Pflege/Kinderbetreuung. 
the following activities." 17 This was followed by three items: (a) housework/shopping; (b) care/childcare; (c) paid work.

Because of the nature of childcare, it is recognised as being difficult to measure and that retrospective measures are not ideal ${ }^{18}$ (Fedick, Pacholok, \& Gauthier 2005; Folbre \& Yoon 2007). The largest part of childcare does not comprise focused, joint activities between parents and children (such as playing, feeding, reading, or dressing), but childcare that takes place while parents do other important activities or are not actively involved, but available to and responsible for nearby children (Wray et al. 2021). When childcare is undefined (as in this study's questions), respondents will conceptualise childcare differently, which makes comparing their responses challenging. In order to harmonise their responses to some degree, childcare and housework time above 12 hours was recoded to 12 hours per day, which concerned $18 \%$ of childcare cases and $0.5 \%$ for housework. Twelve hours was chosen because it was a clear mode, particularly among mothers during the lockdown waves. A robustness check was conducted with the originally stated values, while another contrasted mothers' own estimate with fathers' estimate about their respective partners (and vice versa), which showed close correspondence (see appendix table A1). This reaffirms that despite some reservations about the measures, the estimates are fairly accurate. The largest differences appear for mothers' childcare estimates, which is because they are much more likely than fathers to state high amounts of childcare hours.

The main independent variables are: ${ }^{19}$ Age of the youngest child in the household was dichotomised into $0-5$ and 6-14 years. Number of children was categorised into one versus two and more. Highest level of education was categorised as: Low (ISCED 1, 2, 3b): complete or incomplete primary education; apprenticeship (vocational school); intermediate vocational education school. Medium (ISCED 3a): higher vocational or academic school with university entrance qualifications (in Austria, the Matura). High (ISCED 4-6): University; university of applied sciences; post-secondary and short-cycle tertiary education (Hochschulverwandte Lehranstalt oder Kolleg). Employment was recoded into non-employed, employed part-time (1-29 weekly work hours), and employed full-time (30+ weekly work hours). This was based on the following question for the respondent: "How many hours (including overtime) do you work in your main activity now per week?" ${ }^{20}$ For the partner, it was taken from the time-use question above (number of hours spent on "paid work"). Both questions refer to actual working hours rather than contracted ones. Respondents were also asked whether they switched to working from home because of the pandemic. Table A2 in

17 Original German wording: "Denken Sie an einen typischen Werktag in der letzten Woche. Bitte geben Sie an, wie viel Zeit (in Minuten oder Stunden) Ihr(e) Partner(in) mit folgenden Tätigkeiten verbracht haben.“ Hausarbeit/Einkaufen; Pflege/Kinderbetreuung; Bezahlte Arbeit

18 Ideally, respondents should note their activities in short intervals over one or more days, but such surveys require a large effort and are costly. The last such time use survey was conducted for Austria in 2008/09 (Statistics Austria 2020f).

19 No measure for rural/urban environment was available in the dataset. Occupational sector was not considered due to the low case numbers in the analytical samples. Country of birth (Austria/not Austria) was not considered because the foreign category includes a large diversity of countries of origin.

20 Original German wording: "Wie viele Stunden (inklusive Überstunden) arbeiten Sie in Ihrer Haupttätigkeit jetzt pro Woche?“ 
the appendix shows the distribution of the independent variables. Missing values are generally below $5 \%$ and not reported.

\subsection{Methods}

The empirical analysis consists of two parts. The first part examines the magnitude of childcare and housework hours among mothers and fathers (section 5.1.), but does not consider the partner's details. It shows mean hours for all seven waves, while the three waves from April and May 2020 were studied more thoroughly using linear regression models (pooling waves 2, 5 and 8 ) that differentiated by gender. All independent variables described in the previous section were included. Wave was added as a further control variable and clustered standard errors were used for individuals. As a robustness check, regression models that use original childcare values (not recoded) were also estimated.

The second part focuses on the distribution of care time in couples, as reported from the respondent's point of view (section 5.2.). Because couple information is available from wave 8 onward, descriptive statistics are used for five waves (waves 8 to 20), while multivariate logistic regression models use data collected during wave 8 . The dependent variable distinguished between "mother more" and "same"/"father more," based on the following classification: (a) childcare: mother more ( $>0.5$ hours more per day); same (within 0.5 hours); father more ( $>0.5$ hours more per day); (b) childcare and housework: mother more ( $>1$ hour more per day); same (within 1 hour); father more $\left(>1\right.$ hour more per day) ${ }^{21}$. For (a) and (b), cases where both parents spent zero hours were coded as "same" (Riederer, Buber-Ennser, \& Brzozowska 2019). As a robustness check, regression models were estimated that use "mother more," "same," and "father more" as three separate categories. Independent variables were only considered at the household level, e.g., age of the youngest child, number of children (but not education or working from home). Additionally, two variables were constructed about couples' employment arrangement: (a) Couples' employment: both non-employed; father full-time/mother non-employed; father fulltime/mother part-time; both full-time; other; (b) Difference in daily employment hours: mother more (2+ hours more per day); same (within less than 2 hours); father more (2+ hours more). Cases where both parents reported zero hours were coded as "same."

21 The threshold varies by measure ( 0.5 hours for childcare; 1 hour for childcare and housework; 2 hours for employment), which reflects that mothers' and fathers' values are closer for childcare and housework than for employment. 


\section{Empirical results}

\subsection{Mothers' and fathers' time spent on care work}

Figure 1 depicts mean hours per weekday spent on childcare, housework, and employment among mothers and fathers. ${ }^{22}$ The two April waves are quite similar, especially for mothers, while the results show more difference in May-when kindergartens and schools were still closed, but some restrictions had been lifted. The results document parents' remarkably high total workload during the whole study period. The workload was highest for mothersan average of 13.4 hours on weekdays-during the lockdown period (April). In April, November, and February, the mothers' workload exceeded fathers' by approximately one hour (and by about one-half hour between May and August). The workload was especially high for mothers with children below age six, who engaged in an average of almost 15 hours of care work and employment per day (see appendix table A3 for results by age of the youngest child). While the total workload differed only moderately between mothers and fathers, mothers dedicated much more time to care work than fathers. For example, fathers spent around half as much time on childcare as mothers $(51 \%)$ and more than half $(60 \%)$ as much time on housework across the seven waves. In other words, the amount of housework time was closer between mothers and fathers than childcare time. While for both mothers and fathers childcare time was markedly higher during April and May, the extent of housework did not vary as much during the study period.

Figure 1: Mean hours per weekday spent on childcare, housework, and employment, April 2020 to February 2021

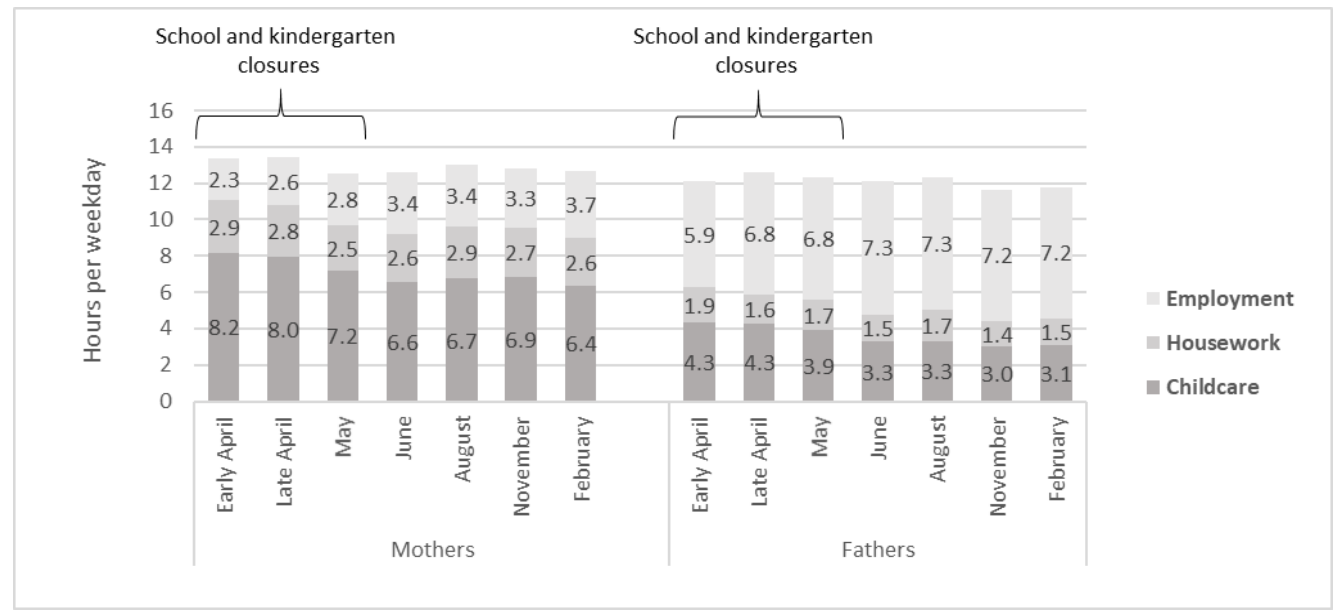

Source: Austrian Corona Panel Project 2020/21 (weighted); waves 2, 5, 8, 11, 14, 17, and 20; respondents in couples with children below age 15 ( $n=104-122$ per wave for mothers; $n=113-136$ per wave for fathers)

22 The results for Germany on childcare from spring 2020 are similar: 9.6 hours among mothers and 5.3 hours among fathers for couples with children up to age 11 (Kreyenfeld \& Zinn 2021). 
Table 3 shows results from the three waves conducted during and immediately after the first lockdown on mean hours per weekday spent on childcare, housework, and total care work (defined as the sum of childcare and housework) by employment characteristics and level of education. The results show clear differences according to employment, with nonemployed parents having spent the most time on childcare and total care work, and fulltime employed parents the least. However, there were remarkable gender contrasts such as mothers spending more time on childcare than fathers when the two parents had similar employment hours. For example, full-time employed mothers spent an average of 6.1 hours per weekday on childcare during the lockdown compared to 3.7 hours among full-time employed fathers. It is also notable that fathers' childcare hours were more dependent on their employment status than mothers. The difference in childcare time between nonemployed and full-time employed mothers was 2.4 hours compared to 3.8 hours between fathers. Likewise, working from home yielded different effects, with employed fathers who worked from home spending around 1.5 hours per day more on childcare than their male counterparts who worked outside the home. Time spent on housework was similar in these two groups. On the other hand, mothers who worked from home spent less time on childcare and housework than their peers who worked on-site. ${ }^{23}$ This was partly due to higher shares of full-time employment among mothers who worked from home - who were often higher educated (see appendix table A4) - compared to mothers who worked on-site (see appendix table A5). Finally, the education results show that low educated mothers spent the most time with their children and highly educated mothers the least. This may be partly explained by differences in employment: Low educated mothers were both non-employed more often and employed full-time less often than their higher educated peers (see appendix table A6). For fathers, a U-shaped relationship was observed wherein fathers with low and high education spent more time on childcare (and also housework) than medium educated fathers.

The results from the regression models for the April and May waves are displayed in table 4 . They show that parents-especially mothers-with a youngest child below age six allocated much more time to childcare than their peers with a school-aged child (model 1). By contrast, the results for the number of children are not significant. Non-employed parents spent more time on childcare and housework than full-time employed parents (the difference between full-time and part-time employed parents was not significant aside from mothers' time spent on housework). However, the effect of employment on childcare was only significant for fathers and considerably larger than for mothers. The effect of working from home was also only significant and positive for fathers (model 4). This generally implies that employment characteristics had a stronger effect on care hours for fathers than for mothers. One interpretation is that mothers were more likely to assume childcare responsibilities independent of whether they worked from home, on-site, or were not employed. In terms of education, higher educated mothers showed significant negative effects concerning childcare (model 4). However, after controlling for employment level (model 1), these effects became non-significant, suggesting that the lower amount of hours spent on childcare by highly educated mother may be largely attributed to their higher share

23 A similar finding was reported for Germany, although the difference was only 0.2 hours (Bujard et al. 2020: $38)$. 
of full-time employment. For fathers, the difference in childcare time between medium and highly educated fathers was significant (model 1), which related to different employment characteristics by educational attainment. First, controlling for working from home (model 4) resulted in the education effect being non-significant. Among medium educated fathers, lower childcare time can be partly explained by their lower prevalence of working from home compared to their higher educated peers. Second, a childcare model that contains level of education but no employment characteristics (not shown) displays a non-significant and less-strong education effect (high education: $1.57 ; \mathrm{p}=0.065$ ) than shown in model 1 . In other words, if highly educated fathers had the same employment levels as their medium educated peers (in particular, a higher share of non-employed fathers), the childcare gap would even be larger. Robustness checks using original childcare values (not recoded to 12 hours) are available in appendix table A7. The results are substantively similar, although mean childcare hours were elevated for mothers for some groups, e.g., by age of the youngest child.

Table 3: Mean hours per weekday spent on childcare, housework and total care work by employment and education, April and May 2020

\begin{tabular}{|c|c|c|c|c|c|c|}
\hline & Mothers & & & Fathers & & \\
\hline & Childcare & Housework & $\begin{array}{l}\text { Total care } \\
\text { work }\end{array}$ & Childcare & Housework & $\begin{array}{l}\text { Total care } \\
\text { work }\end{array}$ \\
\hline \multicolumn{7}{|l|}{ Employment } \\
\hline Non-employed & 8.5 & 2.8 & 11.4 & 7.5 & 2.2 & 9.7 \\
\hline Part-time & 7.5 & 3.0 & 10.4 & 4.3 & 1.7 & 6.0 \\
\hline Full-time & 6.1 & 2.3 & 8.3 & 3.7 & 1.7 & 5.4 \\
\hline \multicolumn{7}{|l|}{$\begin{array}{l}\text { Working from } \\
\text { home (among } \\
\text { employed) }\end{array}$} \\
\hline Yes & 5.8 & 2.3 & 8.1 & 4.9 & 1.6 & 6.5 \\
\hline No & 7.6 & 3.0 & 10.6 & 3.4 & 1.7 & 5.1 \\
\hline \multicolumn{7}{|l|}{ Education } \\
\hline Low education & 8.3 & 2.7 & 10.9 & 4.3 & 1.7 & 6.0 \\
\hline $\begin{array}{l}\text { Medium } \\
\text { education }\end{array}$ & 8.0 & 2.9 & 10.8 & 3.3 & 1.4 & 4.7 \\
\hline High education & 6.7 & 2.8 & 9.4 & 4.4 & 2.1 & 6.6 \\
\hline
\end{tabular}


Table 4: Predictors of mean hours per weekday spent on childcare, housework, and total care work, April and May 2020, linear regression models

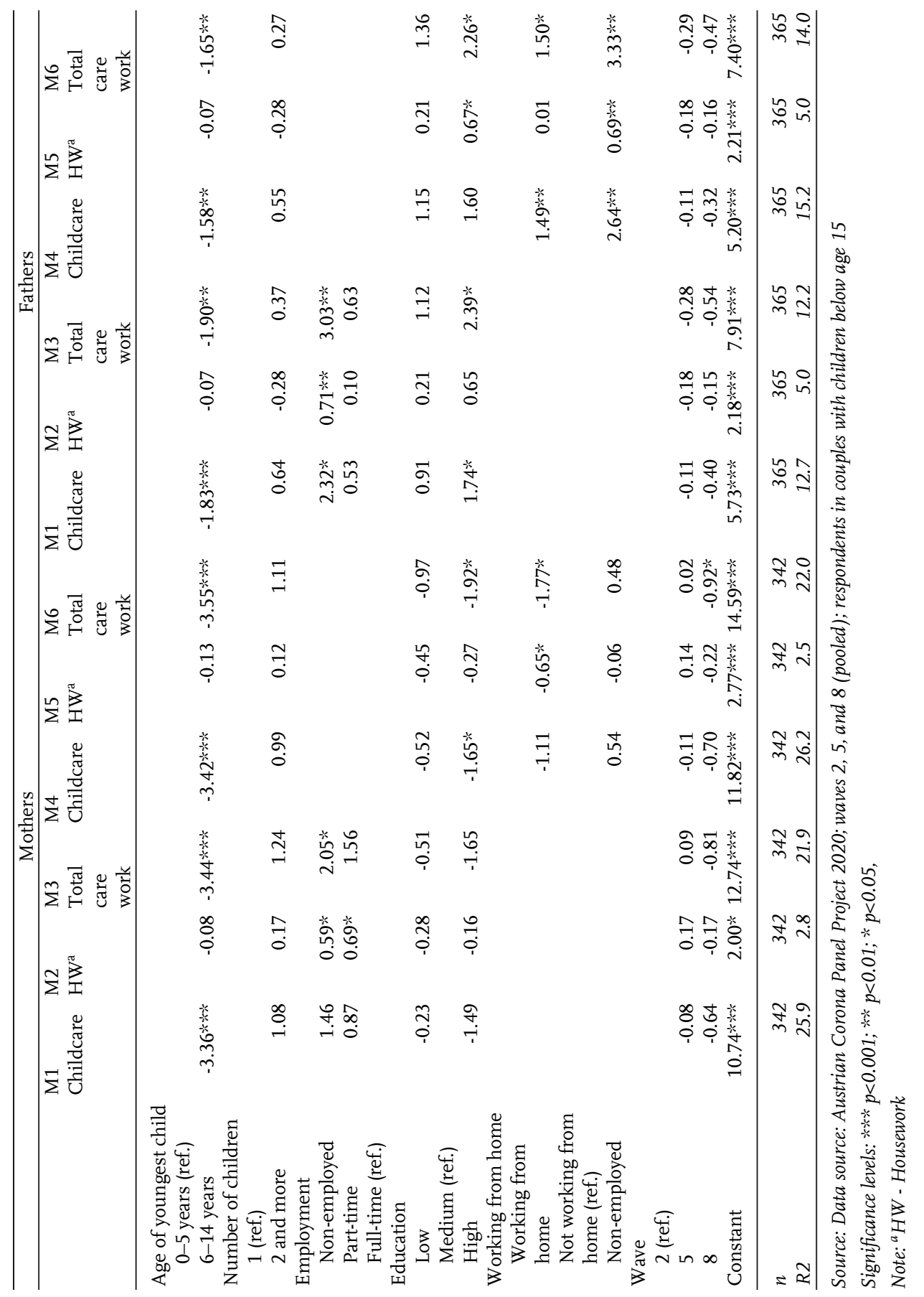




\subsection{Distribution of care work within couples}

The second part of the empirical analysis concentrates on how childcare and total care work was distributed within couples. During the May lockdown, figure 2 shows how mothers spent more time on childcare in $56 \%$ of couples, while $36 \%$ shared the time equally, and fathers spent more time than mothers in $8 \%$ of couples. ${ }^{24}$ The distribution for housework was more balanced with mothers spending more time in $50 \%$ of couples, and fathers spent more time in $18 \%$ of couples. Table A 8 contains figures by age of the youngest child, demonstrating that the distribution of childcare and housework was less equal for couples with younger children.

Figure 2: Distribution of childcare, housework, and total care work in couples, May 2020 to February 2021

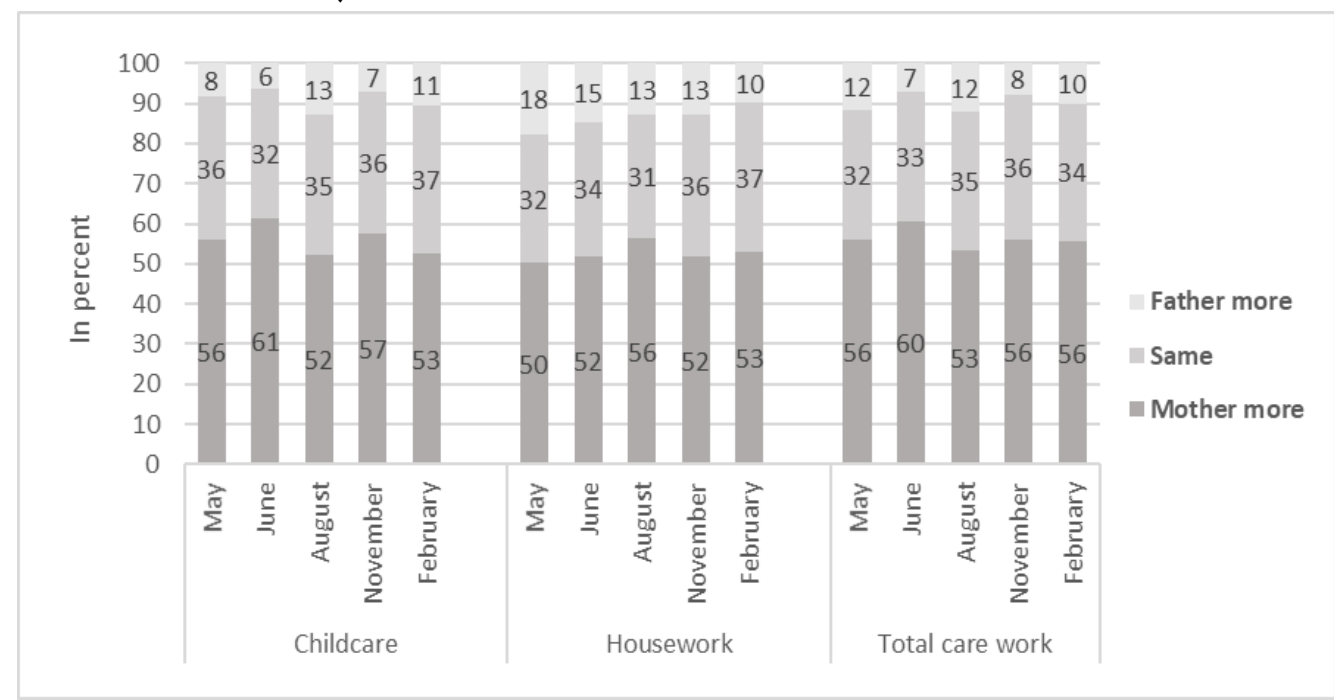

Source: Austrian Corona Panel Project 2020/21 (weighted); waves 8, 11, 14, 17, and 20; respondents in couples with children below age 15 ( $n=220-245$ per wave)

Additional results according to employment from the wave conducted in May (wave 8) show that the distribution was most equal among couples where both were non-employed, followed by dual full-time earners (table 5). The "other" category was also marked by a high level of gender equality, consisting mainly of combinations where both parents were employed part-time or the mother worked more employment hours (e.g., father part-time, mother full-time). In constellations where the father was employed full-time and the mother was either non-employed or employed part-time, the distribution reflected traditional

24 These shares were strikingly similar to the numbers for Germany (pertaining to the period from mid-May to early July) despite different measurements: mothers spent more time on childcare in $62 \%$ of couples, both shared in $33 \%$, and fathers spent more time in $6 \%$. The distribution of housework was more equal in Austria than in Germany. In Germany, mothers spent more time on housework in $59 \%$ of couples, both shared in $34 \%$, and fathers spent more time in 7\% (Hank and Steinbach 2020). 
gender roles where the mother was responsible for most childcare activities (or total care work). It is remarkable that, on the one hand, when fathers' employment hours were higher, mothers usually took over childcare and housework (67\% of cases for total care work). On the other hand, when mothers' employment hours were higher, both parents tended to share care work equally ( $46 \%$ of cases), while fathers took on more work in $33 \%$ of cases

The results from the regression models in table 6 show no significant effects for age of the youngest child or number of children for the May wave. The multivariate findings confirm that the distribution of (child)care time is more equal (or fathers take over more) when parents have the same employment level (either both non-employed or both full-time employed) or when mothers work more employment hours. A robustness check that differentiates between the three dependent variable categories highlights a childcare gap between non-employed versus part-time employed mothers in cases where the father works full-time: When the mother is non-employed, "father more" is significantly less prevalent, but not when the mother is employed part-time (see appendix table A9).

\section{Conclusion}

This study examined both the magnitude of time mothers and fathers spent on childcare and housework during and after the first lockdown as well as the distribution of care work in couples. Parents' total workload (care work and employment) across the entire study period was very high. The amount of time was greatest during the first lockdown for mothers with a youngest child below age six. Mothers' total workload exceeded fathers' by around one hour during this time, which suggests that this period was especially challenging for mothers. Such a high workload is a risk factor for psychological well-being and has been linked to high work-family conflicts and declining partnership quality (Berghammer \& Beham-Rabanser 2020; OECD 2021; Rodrigues et al. 2021). While gender differences in total workload were moderate, mothers performed around twice as much care work than fathers. In the majority of families, mothers thus assumed more care work. However, partners shared work equally in about one third of families, while fathers took over the lion's share in close to $10 \%$ of families.

Regarding the four hypotheses, care work was higher at lower employment levels for both mothers and fathers. This is in line with the time availability approach and supports hypothesis 1a. Full-time employed fathers spent 5.4 hours per weekday on care compared to 6.0 among part-time and 9.7 among non-employed fathers, while the respective numbers were 8.3, 10.4 and 11.4 hours for mothers. The COVID-19 pandemic boosted men's employment arrangements that had previously been almost non-existent, especially concerning part-time employment. In 2019, before the pandemic, only $6 \%$ of fathers worked part-time compared to $74 \%$ of mothers (see footnote 3 ). A higher prevalence of parttime work-along with higher unemployment and working from home-generated more time resources for fathers and, consequently, led to more time dedicated to childcare and housework. By contrast, working from home was associated with less care time for mothers because of a higher share of full-time work; thus, hypothesis $1 \mathrm{~b}$ is only supported for fathers. 
Table 5: Distribution of childcare, housework, and total care work in couples by employment arrangement, May 2020, in \%

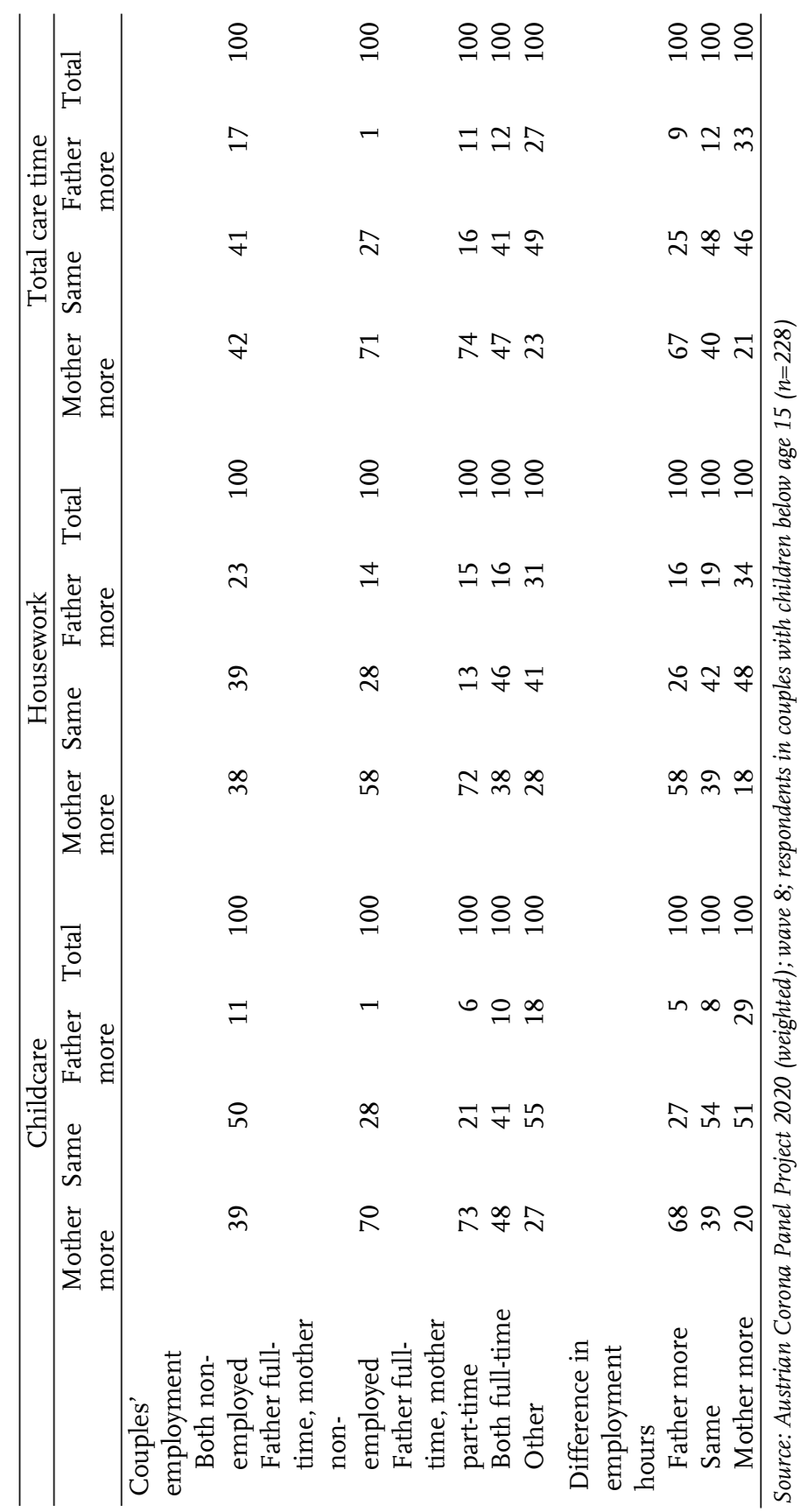


Table 6: Predictors of childcare, housework, and total care work distribution in couples, May 2020, logistic regression models (odds ratios)

\begin{tabular}{|c|c|c|c|c|c|c|}
\hline \multirow{2}{*}{ Reference: Mother more } & \multicolumn{2}{|l|}{ Childcare } & \multicolumn{2}{|c|}{ Housework } & \multicolumn{2}{|c|}{ Total care work } \\
\hline & $\begin{array}{l}\text { Same/ } \\
\text { father } \\
\text { more }\end{array}$ & $\begin{array}{l}\text { Same/ } \\
\text { father } \\
\text { more }\end{array}$ & $\begin{array}{l}\text { Same/ } \\
\text { father } \\
\text { more }\end{array}$ & $\begin{array}{l}\text { Same/ } \\
\text { father } \\
\text { more }\end{array}$ & $\begin{array}{l}\text { Same/ } \\
\text { father } \\
\text { more }\end{array}$ & $\begin{array}{l}\text { Same/ } \\
\text { father } \\
\text { more }\end{array}$ \\
\hline \multicolumn{7}{|l|}{$\begin{array}{l}\text { Age of youngest child } \\
0-5 \text { years (ref.) }\end{array}$} \\
\hline 6-14 years & 0.95 & 1.16 & 1.20 & 1.17 & 0.97 & 1.15 \\
\hline \multicolumn{7}{|l|}{$\begin{array}{l}\text { Number of children } \\
1 \text { (ref.) }\end{array}$} \\
\hline 2 and more & 1.73 & 1.63 & 1.05 & 1.11 & 1.09 & 1.06 \\
\hline \multirow{2}{*}{\multicolumn{7}{|c|}{$\begin{array}{l}\text { Couples' employment } \\
\text { Both full-time (ref.) }\end{array}$}} \\
\hline & & & & & & \\
\hline Both non-employed & 1.19 & & 1.42 & & 1.15 & \\
\hline $\begin{array}{l}\text { Father full-time, mother non- } \\
\text { employed }\end{array}$ & $0.19 * \cdots *$ & & 0.54 & & $0.25 \% *$ & \\
\hline Father full-time, mother part-time & $0.31 * *$ & & $0.24 * 2 * *$ & & $0.33 * *$ & \\
\hline Other & 2.04 & & 1.69 & & 2.09 & \\
\hline \multicolumn{7}{|l|}{ Difference in employment hours } \\
\hline Same/mother more & & 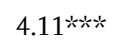 & & $3.07 * \cdots *$ & & $3.34 * * * *$ \\
\hline Constant & 0.61 & $0.04 \times$ & 1.00 & $0.14 *$ & 1.07 & $0.10 * *$ \\
\hline$n$ & 228 & 228 & 228 & 228 & 228 & 228 \\
\hline Pseudo R2 & 12.1 & 8.6 & 7.8 & 5.3 & 10.0 & 6.2 \\
\hline
\end{tabular}

Source: Austrian Corona Panel Project 2020; wave 8; respondents in couples with children below age 15

Significance levels: $* * * p<0.001 ; * * p<0.01 ; * p<0.05$

Second, while lower employment was linked to more care time for both fathers and mothers, the strength of the association differed. The gap between full-time employment and non-employment was considerably larger among fathers (4.3 hours) than mothers (3.1 hours). This finding corresponds to results from other countries (e.g. Hank \& Steinbach 2021), where fathers have increased their care work when they had available time resources, whereas mothers almost always allocated many hours to (child)care irrespective of their time resources (their employment status). This conclusion aligns with gender role theory (and hypothesis 2), which assumes that women and men act according to norms and expectations that conform to traditional gender roles.

Third, this study documented a U-shaped relationship regarding education for fathers and a negative relationship for mothers. As proposed by hypothesis 3, highly educated fathers spent more time on care, followed by low educated fathers. This pattern reflects how highly educated fathers combined childcare and housework with working from home more often, which afforded them more flexibility to reduce or shift their employment hours. Active fatherhood norms could also play a role. However, lower educated fathers were most affected by unemployment and short-time employment. A negative education gradient, as reported for Germany, could thus not be found among fathers in Austria (Kreyenfeld \& Zinn 2021). In contrast to hypothesis 3, care time was lower at a higher level of education for mothers because of a higher involvement in full-time employment. 
Fourth, this study shed light on differences between childcare and housework. As hypothesis 4 a suggested, housework time was shared more equally between partners than childcare time, with fathers spending around half as much time on childcare as mothers (51\% across all waves), but more than half $(60 \%)$ as much on housework. There is mixed international evidence about this issue (Farre et al. 2020; Hank \& Steinbach 2021; Yerkes et al. 2020).

To conclude, although mothers on average shouldered significantly more care time than fathers, COVID-19-related instability in care work and employment also elicited lesstraditional couple arrangements. Some fathers took on new roles for the first time, where they combined less employment with more childcare-as mothers in Austria do. Will such a more-egalitarian division of work persist in the future? The time availability approach would anticipate a return to earlier patterns as soon as available time shrinks again (when employment hours and working from home are back to their pre-COVID-19 state) (e.g. Bünning 2020). Gender role theory would also predict a short-term effect because gender role attitudes will most likely not have shifted abruptly. Yet, some scholars speculate that the shift towards increased gender equality could be more sustainable. After all, fathers have learned new skills, experienced combining work and family life, and couples established new routines for dividing work. Some fathers might have reconsidered their past arrangements after finding that increasing their family time was gratifying. Concerning the United States, Alon et al. (2020) state that, "[i]t is likely that this higher exposure will have at least some persistent effect on future contributions to child care, be it through learning by doing, more information about what kids are actually doing all day, or through increased attachment to children" (Alon et al. 2020: 21). They compare the experiences gained by fathers during the COVID-19 lockdowns with paternity leave, which has long-lasting effects on their childcare involvement. However, unlike paternity leave, fathers did not voluntarily engage in more childcare. Childcare requirements during the first lockdown were excessive and often had to be combined with working from home, which was difficult for parents. There was a lack of external care or most leisure opportunities, which could explain why many families did not find childcare gratifying under these specific circumstances. Overall, it seems reasonable that the experiences gained during the COVID-19 lockdowns could lead to a more permanent change towards increasingly egalitarian roles in some families, but probably not on a large scale.

\section{Data availability statement}

The data of the Austrian Corona Panel are available free of charge from AUSSDA (Austrian Social Science Data Archive) at https://doi.org/10.11587/28KQNS. 


\section{Acknowledgments}

This work was funded by the Austrian Science Fund (FWF) within the project "Couples' division of work during COVID-19 lockdown in Austria" (P 34362). Thanks to Bernhard Riederer for valuable comments and suggestions.

\section{References}

Alon, T., Doepke, M., Olmstead-Rumsey, J. \& Tertilt, M. (2020). The impact of COVID-19 on gender equality. National Bureau of Economic Research Working Paper, 26947. https://doi.org/10.3386/w26947

Bambra, C. (2007). Defamilisation and welfare state regimes: A cluster analysis. International Journal of Social Welfare, 16, 4, 326-338. https://doi.org/10.1111/j.1468-2397.2007.00486.x

Beham-Rabanser, M., Scaria-Braunstein, K., Haring-Mosbacher, S. A., Forstner, M. \& Bacher, J. (forthcoming). Arbeit und Familie im Covid-19-Alltag. In: Aschauer, W., Glatz, C. \& Prandner, D. (Eds.), Die Österreichische Gesellschaft während der CoronaPandemie. Ergebnisse aus sozialwissenschaftlichen Umfragen. Wiesbaden: Springer.

Berghammer, C. (2020a). Alles traditioneller? Arbeitsteilung zwischen Männern und Frauen in der Corona-Krise.

https://viecer.univie.ac.at/corona-blog/corona-blog-beitraege/blog33/ [retrieved June 2020]

Berghammer, C. (2020b). Work-Family-Konflikt in der Corona-Krise. https://viecer.univie.ac.at/corona-blog/corona-blog-beitraege/blog25/ [retrieved June 2020]

Berghammer, C. \& Beham-Rabanser, M. (2020). Die Corona-Krise verändert die Beziehungsqualität: In vielleicht unerwarteter Weise.

https://viecer.univie.ac.at/corona-blog/corona-blog-beitraege/blog42/ [retrieved June 2020]

Blum, S. \& Dobrotić, I. (2021). Childcare-policy responses in the COVID-19 pandemic: Unpacking cross-country variation. European Societies, 23, 1, 545-563.

https://doi.org/10.1080/14616696.2020.1831572

Bock-Schappelwein, J. (2020). Welches Home-Office-Potential birgt der Österreichische Arbeitsmarkt? WIFO Research Brief, 4/2020.

Bock-Schappelwein, J., Famira-Mühlberger, U. \& Mayrhuber, C. (2020). COVID-19: Ökonomische Effekte auf Frauen. WIFO Research Brief, 3/2020.

Bock-Schappelwein, J. \& Mayrhuber, C. (2020). Ökonomische Auswirkungen von Covid-19 auf die Beschäftigungs- und Einkommenslage von Frauen. In: City of Vienna (Ed.), Frauengesundheit und Corona. Vienna, 183-191.

Bujard, M., Laß, I., Diabaté, S., Sulak, H. \& Schneider, N. F. (2020). Eltern während der Corona-Krise. Zur Improvisation gezwungen. Wiesbaden: Bundesinstitut für Bevölkerungsforschung. 
Bundesagentur für Arbeit. (2021). Realisierte Kurzarbeit (hochgerechnet) - Deutschland, Länder, Regionaldirektionen, Agenturen für Arbeit und Kreise (Monatszahlen). Tabelle 1 [retrieved October 2021]

Bünning, M. (2020). Paternal part-time employment and fathers' long-term involvement in child care and housework. Journal of Marriage and Family, 82, 2, 566-586. https://doi.org/10.1111/jomf.12608

Del Boca, D., Oggero, N., Profeta, P. \& Rossi, M. (2020). Women's and men's work, housework and childcare, before and during COVID-19. Review of Economics of the Household, 18, 4, 1001-1017. https://doi.org/10.1007/s11150-020-09502-1

Der Standard. (2021). Schulbesuch im Lockdown: Im Schnitt sind 15 Prozent weiterhin anwesend.

https://www.derstandard.at/story/2000121775865/schulbesuch-im-lockdown-imschnitt-sind-15-prozent-weiterhin-anwesend [retrieved June 2021].

Derndorfer, J., Disslbacher, F., Lechinger, V., Mader, K. \& Six, E. (2021). Home, sweet home? The impact of working from home on the division of unpaid work during the COVID-19 lockdown. INEQ Working Paper Series, 21, WU Vienna University of Economics and Business, Vienna.

Dotti Sani, G. M. \& Treas, J. (2016). Educational gradients in parents' child-care time across countries, 1965-2012. Journal of Marriage and Family, 78, 4, 1083-1096. https://doi.org/10.1111/jomf.12305

Eagly, A. H. \& Wood, W. (2016). Social role theory of sex differences. In: Wong, A., Wickramasinghe, M., Hoogland, R. \& Naples, N.A. (Eds.), The Wiley Blackwell Encyclopedia of Gender and Sexuality Studies. New York: Wiley, 1-3. https://doi.org/10.1002/9781118663219.wbegss 183

Eurostat database. (2020). Employment and activity by sex and age - annual data [lfsi_emp_a].

Farre, L., Fawaz, Y., Gonzalez, L. \& Graves, J. (2020). How the COVID-19 lockdown affected gender inequality in paid and unpaid work in Spain. IZA Discussion Paper No. 13434.

Fauser, S. (2019). Time availability and housework: The effect of unemployment on couples' hours of household labor. Social Science Research, 83, 102304. https://doi.org/10.1016/j.ssresearch.2019.04.017

Fedick, C. B., Pacholok, S. \& Gauthier, A. H. (2005). Methodological issues in the estimation of parental time - analysis of measures in a Canadian time-use survey. Electronic International Journal of Time Use Research, 2, 1, 67-87. https://dx.doi.org/10.13085/eIJTUR.2.1.67-87

Folbre, N. \& Yoon, J. (2007). What is child care? Lessons from time-use surveys of major English-speaking countries. Review of Economics of the Household, 5, 3, 223-248. https://doi.org/10.1007/s11150-007-9012-3

Geist, C. \& Ruppanner, L. (2018). Mission impossible? New housework theories for changing families. Journal of Family Theory \& Review, 10, 1, 242-262. https://doi.org/10.1111/jftr.12245

Gough, M. \& Killewald, A. (2011). Unemployment in families: The case of housework. Journal of Marriage and Family, 73, 5, 1085-1100. https://doi.org/10.1111/j.1741-3737.2011.00867.x 
Hank, K. \& Steinbach, A. (2021). The virus changed everything, didn't it? Couples' division of housework and childcare before and during the Corona crisis. Journal of Family Research, 33, 1, 99-114. https://doi.org/10.20377/jfr-488

Hipp, L. \& Bünning, M. (2020). Parenthood as a driver of increased gender inequality during COVID-19? Exploratory evidence from Germany. European Societies, 1-16. https://doi.org/10.1080/14616696.2020.1833229

Kittel, B., Kritzinger, S., Boomgaarden, H., Prainsack, B., Eberl, J.-M., Kalleitner, F., Lebernegg, N. S., Partheymüller, J., Plescia, C., Schiestl, D. W. \& Schlogl, L. (2020). Austrian Corona Panel Project (SUF edition). https://doi.org/10.11587/28KQNS

Kittel, B., Kritzinger, S., Boomgaarden, H., Prainsack, B., Eberl, J.-M., Kalleitner, F., Lebernegg, N. S., Partheymüller, J., Plescia, C., Schiestl, D. W. \& Schlogl, L. (2021). The Austrian Corona Panel Project: Monitoring individual and societal dynamics amidst the COVID-19 crisis. European Political Science, 20, 2, 318-344. https://doi.org/10.1057/s41304-020-00294-7

Kittel, B., Pollak, M. \& Partheymüller, J. (2020). Kinderbetreuung in Zeiten von Corona: Kein Problem?

https://viecer.univie.ac.at/corona-blog/corona-blog-beitraege/blog67/ [retrieved June 2020]

Kleven, H., Landais, C., Posch, J., Steinhauer, A. \& Zweimüller, J. (2019). Child penalties across countries: Evidence and explanations. NBER Working Paper No. 25524, https://www.nber.org/papers/w25524.pdf.

Kreyenfeld, M. \& Zinn, S. (2021). Coronavirus and care: How the coronavirus crisis affected fathers' involvement in Germany. Demographic Research, 44, 4, 99-124. https://doi.org/10.4054/DemRes.2021.44.4

Maume, D. J. (2008). Gender differences in providing urgent childcare among dual-earner parents. Social Forces, 87, 1, 273-297. https://doi.org/10.1353/sof.0.0101

Möhring, K., Naumann, E., Reifenscheid, M., Blom, A. G., Wenz, A., Rettig, T., Lehrer, R., Krieger, U., Juhl, S., Friedel, S., Fikel, M. \& Cornesse, C. (2020). Die Mannheimer Corona-Studie: Schwerpunktbericht zu Erwerbstätigkeit und Kinderbetreuung. https://madoc.bib.uni-mannheim.de/55139/1/2020-0405_Schwerpunktbericht_Erwerbstaetigkeit_und_Kinderbetreuung.pdf

OECD. (2021). Tackling the mental health impact of the COVID-19 crisis: An integrated, wholeof-society response. OECD Publishing: Paris.

Pichler, P., Schmidt-Dengler, P. \& Zulehner, C. (2020). Von Kurzarbeit und Kündigungen sind sozial schwächere Personen am meisten betroffen: Die Arbeitssituation der Österreicher*innen seit der Corona-Krise. https://viecer.univie.ac.at/corona-blog/corona-blog-beitraege/blog09/ [retrieved June 2020]

Pieh, C., Budimir, S. \& Probst, T. (2020). The effect of age, gender, income, work, and physical activity on mental health during coronavirus disease (COVID-19) lockdown in Austria. Journal of Psychosomatic Research, 136, 110186.

https://doi.org/10.1016/j.jpsychores.2020.110186 
Pollak, M., Kowarz, N. \& Partheymüller, J. (2020). Chronologie zur Corona-Krise in Österreich - Teil 2: Von den ersten Lockerungen hin zu einer Normalisierung des öffentlichen Lebens. https://viecer.univie.ac.at/corona-blog/corona-blog-beitraege/blog60/ [retrieved February 2021]

Riederer, B., Buber-Ennser, I. \& Brzozowska, Z. (2019). Fertility intentions and their realization in couples: How the division of household chores matters. Journal of Family Issues, 40, 13, 1860-1882. https://doi.org/10.1177/0192513x19848794

Rodrigues, R., Simmons, C., Schmidt, A. E. \& Steiber, N. (2021). Care in times of COVID19: The impact of the pandemic on informal caregiving in Austria. European Journal of Ageing, 18, 2, 195-205. https://doi.org/10.1007/s10433-021-00611-z

Schönherr, D. (2020). Zur Situation von Eltern während der Coronapandemie. SORA Endbericht. https://www.sora.at/fileadmin/downloads/projekte/2020_20133_Momentum_Elternb efragung_Corona_Endbericht.pdf [retrieved June 2020]

Six, E., Mader, K., Lechinger, V., Disslbacher, F. \& Derndorfer, J. (2020). Frauen in der Krise? Folgen der Coronapandemie für die Verteilung der Sorgearbeit. In: City of Vienna (Ed.), Frauengesundheit und Corona. Vienna, 163-172.

Statistics Austria. (2009). Zeitverwendung 2008/09. Ein Überblick über geschlechtsspezifische Unterschiede.

https://www.statistik.at/web_de/statistiken/menschen_und_gesellschaft/soziales/zeit verwendung/zeitverwendungserhebung/index.html [retrieved June 2021]

Statistics Austria. (2020a). COVID-19 Prävalenzstudien. https://www.statistik.at/web_de/statistiken/menschen_und_gesellschaft/gesundheit/ Co19/index.html [retrieved February 2021]

Statistics Austria. (2020b). COVID-19 Prävalenzstudien: Arbeitssituation, Arbeitsort (April 2020).

https://www.statistik.at/web_de/statistiken/menschen_und_gesellschaft/gesundheit/ covid19/index.html [retrieved February 2021]

Statistics Austria. (2020c). Der Arbeitsmarkt während der Corona-Krise Arbeitsmarktdaten April 2020. Pressemitteilung: 12.254-094/20.

Statistics Austria. (2020d). Entwicklung der aktiven Erwerbstätigen- und Teilzeitquoten (ilo) der 15- bis 64-Jährigen nach Alter des jüngsten Kindes und Geschlecht, 1994 - 2019. http://www.statistik.at/web_de/statistiken/menschen_und_gesellschaft/arbeitsmarkt/ familie_und_arbeitsmarkt/080123.html [retrieved June 2020]

Statistics Austria. (2020e). Paare mit Kindern unter 18 Jahren nach Merkmalen der Erwerbstätigkeit (ilo) und Alter des jüngsten Kindes, 2019.

https://www.statistik.at/web_de/statistiken/menschen_und_gesellschaft/arbeitsmarkt /familie_und_arbeitsmarkt/080127.html [retrieved June 2020]

Statistics Austria. (2020f). Zeitverwendungserhebung 2008/09.

https://www.statistik.at/web_de/statistiken/menschen_und_gesellschaft/soziales/zeit verwendung/zeitverwendungserhebung/index.html [retrieved June 2020] 
Steiber, N., Berghammer, C. \& Haas, B. (2016). Contextualizing the education effect on women's employment: A cross-national comparative analysis. Journal of Marriage and Family, 78, 1, 246-261. https://doi.org/10.1111/jomf.12256

Steiber, N. \& Haas, B. (2010). Begrenzte Wahl - Gelegenheitsstrukturen und Erwerbsmuster in Paarhaushalten im europäischen Vergleich. Kölner Zeitschrift für Soziologie und Sozialpsychologie, 62, 2, 247-276. http://dx.doi.org/10.1007/s11577-010-0103-4

Steiber, N., Siegert, C. \& Vogtenhuber, S. (2021). The impact of the COVID-19 pandemic on the employment situation and financial well-being of families with children in Austria: Evidence from the first ten months of the crisis. Journal of Family Research. https://doi.org/10.20377/jfr-721

Vogtenhuber, S. \& Steiber, N. (2021). Registerbasierte Erwerbsverläufe in der COVID-19 Pandemie in Österreich [Web Application, Version 1]. https://go.ihs.ac.at/COV19AT [retrieved November 2021]

Wernhart, G., Dörfler, S., Halbauer, S., Mazal, W. \& Neuwirth, N. (2018). Familienzeit - wie die Erwerbsarbeit den Takt vorgibt. Perspektiven zu einer Neugestaltung der Arbeitszeit. Forschungsbericht 25, Austrian Institute for Family Studies.

Wray, D., Ingenfeld, J., Milkie, M. A. \& Boeckmann, I. (2021). Beyond childcare: Changes in the amount and types of parent-child time over three decades. Canadian Review of Sociology/Revue canadienne de sociologie, 58, 3, 327-351. https://doi.org/10.1111/cars.12356

Yerkes, M. A., André, S. C. H., Besamusca, J. W., Kruyen, P. M., Remery, C. L. H. S., van der Zwan, R., Beckers, D. G. J. \& Geurts, S. A. E. (2020). 'Intelligent' lockdown, intelligent effects? Results from a survey on gender (in)equality in paid work, the division of childcare and household work, and quality of life among parents in the Netherlands during the COVID-19 lockdown. PLOS ONE, 15, 11, e0242249. https://doi.org/10.1371/journal.pone.0242249

Zamberlan, A., Gioachin, F. \& Gritti, D. (2021). Work less, help out more? The persistence of gender inequality in housework and childcare during UK COVID-19. Research in Social Stratification and Mobility, 100583. https://doi.org/10.1016/j.rssm.2021.100583

Zartler, U., Dafert, V., Harter, S. \& Dirnberger, P. (2021). Frauen in Wien und COVID-19. Vienna: City of Vienna. 


\section{Appendix}

Table A1: Comparison of mothers'/fathers' estimates of own mean hours of childcare and housework with fathers'/mothers' estimates of partners

\begin{tabular}{|c|c|c|c|c|c|}
\hline & $\begin{array}{l}\text { Wave } 8 \\
\text { May }\end{array}$ & $\begin{array}{l}\text { Wave } 11 \\
\text { June }\end{array}$ & $\begin{array}{l}\text { Wave } 14 \\
\text { August }\end{array}$ & $\begin{array}{l}\text { Wave } 17 \\
\text { November }\end{array}$ & $\begin{array}{r}\text { Wave } 20 \\
\text { February }\end{array}$ \\
\hline \multicolumn{6}{|l|}{ Childcare } \\
\hline Mothers' estimate & 7.2 & 6.6 & 6.7 & 6.9 & 6.4 \\
\hline Fathers' estimate of partner & 6.0 & 5.4 & 5.2 & 5.2 & 5.0 \\
\hline Fathers' estimate & 3.9 & 3.3 & 3.3 & 3.0 & 3.1 \\
\hline Mothers' estimate of partner & 3.6 & 3.7 & 3.3 & 3.6 & 3.7 \\
\hline \multicolumn{6}{|l|}{ Housework } \\
\hline Mothers' estimate & 2.5 & 2.6 & 2.9 & 2.7 & 2.6 \\
\hline Fathers' estimate of partner & 2.5 & 2.6 & 2.7 & 2.4 & 2.6 \\
\hline Fathers' estimate & 1.7 & 1.5 & 1.7 & 1.4 & 1.5 \\
\hline Mothers' estimate of partner & 1.6 & 1.8 & 1.5 & 1.5 & 1.6 \\
\hline
\end{tabular}

Source: Austrian Corona Panel Project 2020/21 (weighted); respondents in couples with children below age 15 
Table A2: Distribution of independent variables, in \%

\begin{tabular}{|c|c|c|c|c|c|c|c|c|}
\hline & $\begin{array}{l}\text { Wave } \\
\text { All } \\
\text { waves }\end{array}$ & $\begin{array}{l}2 \\
\text { Early } \\
\text { April } \\
\end{array}$ & $\begin{array}{l}5 \\
\text { Late } \\
\text { April } \\
\end{array}$ & $\begin{array}{l}8 \\
\text { May }\end{array}$ & $\begin{array}{l}11 \\
\text { June }\end{array}$ & $\begin{array}{l}14 \\
\text { August }\end{array}$ & $\begin{array}{l}17 \\
\text { November }\end{array}$ & $\begin{array}{l}20 \\
\text { February }\end{array}$ \\
\hline \multicolumn{9}{|l|}{ Gender } \\
\hline Mothers & 49 & & & & & & & \\
\hline Fathers & 51 & & & & & & & \\
\hline \multicolumn{9}{|l|}{ Age of the youngest child } \\
\hline $0-5$ years & 52 & & & & & & & \\
\hline $6-14$ years & 48 & & & & & & & \\
\hline \multicolumn{9}{|l|}{ Number of children } \\
\hline One & 58 & & & & & & & \\
\hline Two and more & 42 & & & & & & & \\
\hline \multicolumn{9}{|l|}{ Highest level of education } \\
\hline \multicolumn{9}{|l|}{ Mothers } \\
\hline Low & 55 & & & & & & & \\
\hline Medium & 25 & & & & & & & \\
\hline High & 20 & & & & & & & \\
\hline \multicolumn{9}{|l|}{ Fathers } \\
\hline Low & 71 & & & & & & & \\
\hline Medium & 18 & & & & & & & \\
\hline High & 11 & & & & & & & \\
\hline \multicolumn{9}{|l|}{ Employment } \\
\hline \multicolumn{9}{|l|}{ Mothers } \\
\hline Non-employed & & 53 & 51 & 43 & 37 & 43 & 34 & 35 \\
\hline Part-time (1-29 hours) & & 32 & 27 & 32 & 35 & 32 & 46 & 41 \\
\hline Full-time (30+ hours) & & 15 & 22 & 25 & 28 & 25 & 20 & 25 \\
\hline \multicolumn{9}{|l|}{ Fathers } \\
\hline Non-employed & & 13 & 10 & 7 & 3 & 7 & 9 & 5 \\
\hline Part-time (1-29 hours) & & 30 & 22 & 19 & 16 & 14 & 12 & 15 \\
\hline Full-time (30+ hours) & & 57 & 68 & 74 & 81 & 80 & 79 & 80 \\
\hline \multicolumn{9}{|l|}{ Couples' employment } \\
\hline Both non-employed & & & & 11 & 7 & 9 & 13 & 7 \\
\hline $\begin{array}{l}\text { Father full-time, mother } \\
\text { non-employed }\end{array}$ & & & & 26 & 28 & 30 & 17 & 27 \\
\hline $\begin{array}{l}\text { part-time } \\
\text { Both full-time }\end{array}$ & & & & $\begin{array}{l}19 \\
27\end{array}$ & $\begin{array}{l}21 \\
29\end{array}$ & 28 & $\begin{array}{l}20 \\
29\end{array}$ & $\begin{array}{l}24 \\
24\end{array}$ \\
\hline Other & & & & 16 & 15 & 15 & 15 & 17 \\
\hline \multicolumn{9}{|l|}{ Difference in employment } \\
\hline \multicolumn{9}{|l|}{ hours } \\
\hline Father more & & & & 59 & 63 & 57 & 52 & 61 \\
\hline Same & & & & 31 & 28 & 33 & 39 & 27 \\
\hline Mother more & & & & 10 & 9 & 10 & 8 & 12 \\
\hline \multicolumn{9}{|l|}{$\begin{array}{l}\text { Working from home } \\
\text { (among employed) }\end{array}$} \\
\hline \multicolumn{9}{|l|}{ Mothers } \\
\hline Yes & & 41 & 43 & 35 & 25 & 13 & 23 & 26 \\
\hline No & & 59 & 57 & 65 & 75 & 87 & 77 & 74 \\
\hline \multicolumn{9}{|l|}{ Fathers } \\
\hline Yes & & 37 & 32 & 26 & 17 & 16 & 26 & 20 \\
\hline No & & 63 & 68 & 74 & 83 & 84 & 74 & 80 \\
\hline
\end{tabular}

Source: Austrian Corona Panel Project 2020/21 (weighted); respondents in couples with children below age 15 
Table A3: Mean hours per weekday with childcare, housework, and employment by age of the youngest child

\begin{tabular}{|c|c|c|c|c|c|c|c|}
\hline & $\begin{array}{l}\text { Early } \\
\text { April }\end{array}$ & $\begin{array}{l}\text { Late } \\
\text { April }\end{array}$ & May & June & August & November & February \\
\hline \multicolumn{8}{|l|}{ MOTHERS } \\
\hline \multicolumn{8}{|c|}{ (a) Youngest child 0-5 years ${ }^{1}$} \\
\hline Childcare & 10.0 & 9.6 & 9.4 & 8.6 & 8.6 & 8.8 & 8.7 \\
\hline Housework & 3.1 & 2.8 & 2.8 & 2.7 & 3.1 & 2.9 & 2.8 \\
\hline Employment & 1.6 & 2.0 & 1.8 & 2.4 & 2.3 & 2.3 & 3.0 \\
\hline Total & 14.7 & 14.4 & 14.0 & 13.7 & 14.0 & 14.0 & 14.5 \\
\hline \multicolumn{8}{|c|}{ (b) Youngest child 6-14 years ${ }^{2}$} \\
\hline Childcare & 6.0 & 6.0 & 4.8 & 4.4 & 4.5 & 4.6 & 3.6 \\
\hline Housework & 2.6 & 2.8 & 2.2 & 2.6 & 2.6 & 2.4 & 2.3 \\
\hline Employment & 3.2 & 3.3 & 3.9 & 4.4 & 4.5 & 4.1 & 4.4 \\
\hline Total & 11.8 & 12.1 & 10.9 & 11.4 & 11.6 & 11.1 & 10.3 \\
\hline \multicolumn{8}{|l|}{ FATHERS } \\
\hline \multicolumn{8}{|c|}{ (a) Youngest child 0-5 years ${ }^{3}$} \\
\hline Childcare & 4.9 & 5.5 & 5.0 & 4.4 & 4.3 & 3.8 & 3.9 \\
\hline Housework & 1.8 & 1.7 & 1.5 & 1.5 & 1.6 & 1.3 & 1.5 \\
\hline Employment & 5.7 & 6.2 & 6.5 & 7.3 & 6.8 & 6.8 & 7.1 \\
\hline Total & 12.4 & 13.4 & 13.0 & 13.2 & 12.7 & 11.9 & 12.5 \\
\hline \multicolumn{8}{|c|}{ (b) Youngest child 6-14 years ${ }^{4}$} \\
\hline Childcare & 3.7 & 2.9 & 2.7 & 2.2 & 2.5 & 2.2 & 2.3 \\
\hline Housework & 2.1 & 1.5 & 1.8 & 1.5 & 1.8 & 1.5 & 1.4 \\
\hline Employment & 6.0 & 7.4 & 7.1 & 7.4 & 7.7 & 7.6 & 7.3 \\
\hline Total & 11.8 & 11.8 & 11.6 & 11.1 & 12.0 & 11.3 & 11.0 \\
\hline
\end{tabular}

Note: ${ }^{1} \mathrm{n}=54-64$ per wave, ${ }^{2} \mathrm{n}=48-61$ per wave, ${ }^{3} \mathrm{n}=53-72$ per wave, ${ }^{4} \mathrm{n}=56-69$ per wave

Source: Austrian Corona Panel Project 2020/21 (weighted); waves 2, 5, 8, 11, 14, 17, and 20; respondents in couples with children below age 15 
Table A4: Working from home by level of education, April and May 2020, in \%

\begin{tabular}{llllllll}
\hline & $\begin{array}{l}\text { Mothers } \\
\text { Not working from } \\
\text { home }\end{array}$ & $\begin{array}{l}\text { Working from } \\
\text { home }\end{array}$ & Total & $\begin{array}{l}\text { Fathers } \\
\text { Not working from } \\
\text { home }\end{array}$ & $\begin{array}{l}\text { Working from } \\
\text { home }\end{array}$ & Total \\
\hline Low & 89 & 11 & 100 & 77 & 23 & 100 \\
Medium & 44 & 56 & 100 & 56 & 44 & 100 \\
High & 45 & 55 & 100 & 47 & 53 & 100 \\
Total & 61 & 39 & 100 & 68 & 32 & 100 \\
\hline
\end{tabular}

Source: Austrian Corona Panel Project 2020 (weighted); waves 2, 5, and 8 (pooled); respondents in couples with children below age 15 ( $n=182$ for mothers; $n=328$ for fathers)

Table A5: Employment by working from home, April and May 2020, in \%

\begin{tabular}{|c|c|c|c|c|c|c|}
\hline & $\begin{array}{l}\text { Mothers } \\
\text { Part-time }\end{array}$ & Full-time & Total & $\begin{array}{l}\text { Fathers } \\
\text { Part-time }\end{array}$ & Full-time & Total \\
\hline Not working from home & 66 & 34 & 100 & 23 & 77 & 100 \\
\hline Working from home & 50 & 50 & 100 & 33 & 67 & 100 \\
\hline Total & 60 & 40 & 100 & 26 & 74 & 100 \\
\hline
\end{tabular}

Source: Austrian Corona Panel Project 2020 (weighted); waves 2, 5, and 8 (pooled); respondents in couples with children below age 15 ( $n=182$ for mothers; $n=328$ for fathers)

Table A6: Employment by level of education, April and May 2020, in \%

\begin{tabular}{llllllllll}
\hline & $\begin{array}{l}\text { Mothers } \\
\text { Non- } \\
\text { employed }\end{array}$ & \multicolumn{2}{c}{$\begin{array}{l}\text { Part- } \\
\text { time }\end{array}$} & $\begin{array}{l}\text { Full- } \\
\text { time }\end{array}$ & Total $\begin{array}{l}\text { Fathers } \\
\text { Non- } \\
\text { employed }\end{array}$ & $\begin{array}{l}\text { Part- } \\
\text { time }\end{array}$ & $\begin{array}{l}\text { Full- } \\
\text { time }\end{array}$ & Total \\
\hline Low & 62 & 25 & 13 & 100 & 12 & 22 & 66 & 100 \\
Medium & 31 & 46 & 23 & 100 & 9 & 19 & 72 & 100 \\
High & 41 & 28 & 32 & 100 & 0 & 37 & 63 & 100 \\
Total & 49 & 31 & 21 & 100 & 10 & 24 & 66 & 100 \\
\hline
\end{tabular}

Source: Austrian Corona Panel Project 2020 (weighted); waves 2, 5, 8 (pooled); respondents in couples with children below age 15 ( $n=342$ for mothers; $n=365$ for fathers) 
Table A7: Predictors of mean hours per weekday with childcare, April and May 2020, linear regression models; comparison of original childcare values and recoded to 12 hours

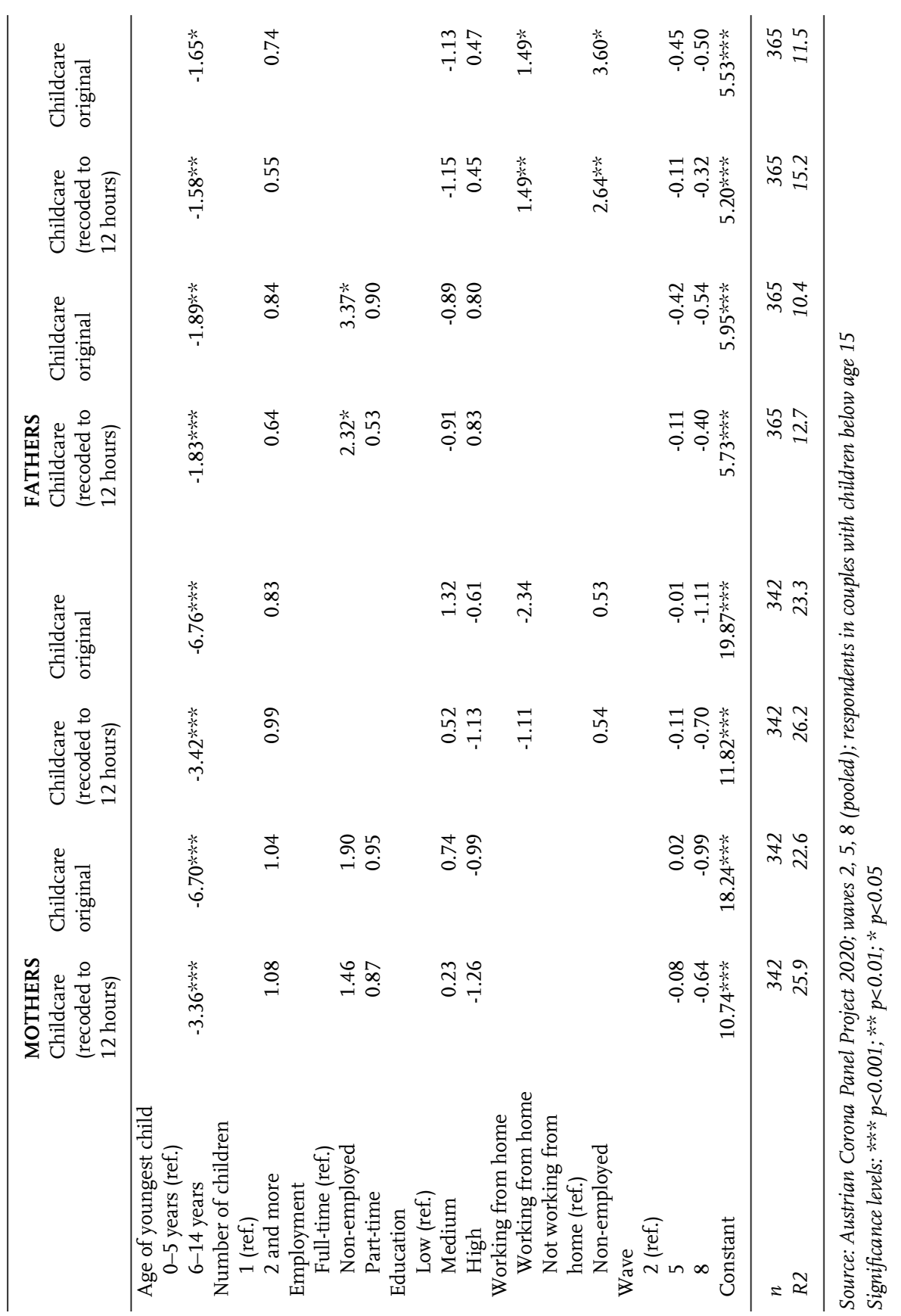


Table A8: Distribution of care work between mothers and fathers by age of the youngest child, in \%

\begin{tabular}{|c|c|c|c|c|c|c|c|c|c|c|c|c|c|c|c|}
\hline & \multicolumn{5}{|c|}{ Childcare } & \multicolumn{5}{|c|}{ Housework } & \multicolumn{5}{|c|}{ Total care work } \\
\hline & May & June & Aug. & Nov. & Feb. & May & June & Aug. & Nov. & Feb. & May & June & Aug. & Nov. & Feb. \\
\hline \multicolumn{16}{|c|}{ (a) Youngest child $0-5$ years $^{1}$} \\
\hline $\begin{array}{l}\text { Father } \\
\text { more }\end{array}$ & 9 & 7 & 11 & 5 & 12 & 18 & 18 & 11 & 8 & 11 & 12 & 6 & 10 & 7 & 12 \\
\hline Same & 33 & 28 & 23 & 35 & 28 & 26 & 27 & 27 & 34 & 34 & 30 & 25 & 24 & 30 & 25 \\
\hline $\begin{array}{l}\text { Mother } \\
\text { more }\end{array}$ & 59 & 65 & 66 & 59 & 60 & 55 & 55 & 62 & 58 & 55 & 58 & 69 & 66 & 63 & 63 \\
\hline \multicolumn{16}{|c|}{ (b) Youngest child 6-14 years ${ }^{2}$} \\
\hline $\begin{array}{l}\text { Father } \\
\text { more }\end{array}$ & 8 & 6 & 15 & 9 & 9 & 17 & 11 & 15 & 18 & 8 & 12 & 8 & 14 & 9 & 8 \\
\hline Same & 39 & 36 & 47 & 36 & 47 & 39 & 40 & 35 & 37 & 41 & 35 & 40 & 46 & 42 & 45 \\
\hline $\begin{array}{l}\text { Mother } \\
\text { more }\end{array}$ & 53 & 57 & 38 & 55 & 44 & 44 & 49 & 50 & 45 & 50 & 53 & 52 & 40 & 49 & 47 \\
\hline
\end{tabular}

Note: ${ }^{1} \mathrm{n}=107-130$ per wave, ${ }^{2} \mathrm{n}=109-126$ per wave

Source: Austrian Corona Panel Project 2020/21 (weighted); waves 8, 11, 14, 17, and 20; respondents in couples with children below age 15

Table A9: Predictors of distribution of childcare, housework, and total care work in couples ( 3 categories), May 2020, multinomial logistic regression models

\begin{tabular}{|c|c|c|c|c|c|c|}
\hline \multirow[b]{2}{*}{ Reference: Mother more } & \multicolumn{2}{|l|}{ Childcare } & \multicolumn{2}{|l|}{ Housework } & \multicolumn{2}{|c|}{ Total care work } \\
\hline & $\begin{array}{l}\text { Father } \\
\text { more }\end{array}$ & Same & $\begin{array}{l}\text { Father } \\
\text { more }\end{array}$ & Same & $\begin{array}{l}\text { Father } \\
\text { more }\end{array}$ & Same \\
\hline $\begin{array}{l}\text { Age of youngest child } \\
0-5 \text { years (ref.) }\end{array}$ & & & & & & \\
\hline 6-14 years & 0.79 & 1.00 & 1.13 & 1.23 & 0.94 & 0.97 \\
\hline $\begin{array}{l}\text { Number of children } \\
1 \text { (ref.) }\end{array}$ & & & & & & \\
\hline 2 and more & 0.75 & $2.10 *$ & 1.32 & 0.93 & 0.62 & 1.31 \\
\hline $\begin{array}{l}\text { Couples' employment } \\
\text { Both full-time (ref.) }\end{array}$ & & & & & & \\
\hline $\begin{array}{l}\text { Both non-employed } \\
\text { Father full-time mother }\end{array}$ & 1.59 & 1.09 & 2.35 & 1.12 & 2.03 & 0.93 \\
\hline $\begin{array}{l}\text { non-employed } \\
\text { Father full-time, mother }\end{array}$ & $0.09 *$ & $0.22 * *$ & 0.55 & 0.55 & $0.10 *$ & $0.28 * *$ \\
\hline part-time & 0.33 & $0.31 * *$ & 0.48 & $0.17 * * *$ & 0.56 & $0.27 * *$ \\
\hline Other & 2.50 & 1.92 & 3.04 & 1.29 & $3.77 *$ & 1.64 \\
\hline Constant & 0.51 & 0.34 & 0.18 & 0.85 & 0.49 & 0.65 \\
\hline$n$ & 228 & 228 & 228 & 228 & 228 & 228 \\
\hline Pseudo R2 & 10.4 & 10.4 & 6.6 & 6.6 & 9.1 & 9.1 \\
\hline
\end{tabular}

Data source: Austrian Corona Panel Project 2020; wave 8; respondents in couples with children below age 15 Significance levels: *** $p<0.001 ; * * p<0.01 ; * p<0.05$ 


\section{Information in German}

\section{Deutscher Titel}

Kinderbetreuung und Hausarbeit während des ersten Lockdowns in Österreich: Traditionelle Aufteilung oder neue Rollen?

\section{Zusammenfassung}

Fragestellung: Diese Studie untersucht, wie viel Zeit Mütter und Väter während und nach dem ersten COVID-19 Lockdown in Österreich (welcher Mitte März 2020 begann) für Kinderbetreuung und Hausarbeit aufwendeten und wie sie diese Zeit untereinander aufteilten.

Hintergrund: Eltern mussten Kinderbetreuungs- und Hausarbeitszeit (Care-Arbeit) neu verteilen, da einerseits Kindergärten und Schulen zwei Monate lang geschlossen blieben, und es andererseits erwerbsbezogene Veränderungen gab, z. B. Homeoffice. Die Ergebnisse werden vor dem Hintergrund zentraler Theorien zur Aufteilung von CareArbeit diskutiert: dem „time availability approach“ und Geschlechterrollentheorie.

Methode: Die Studie verwendet die Daten des Austrian Corona Panel Projects 2020/21, eine webbasierte Umfrage auf Grundlage einer Quotenstichprobe, welche in der zweiten Woche des ersten Lockdowns begann ( $\mathrm{n}=372$ Befragte in Paaren mit Kindern unter 15 Jahre). Insgesamt beinhalten sieben Wellen Informationen $\mathrm{zu}$ der mit Kinderbetreuung und Hausarbeit verwendeten Zeit; drei davon wurden im oder unmittelbar nach dem ersten Lockdown durchgeführt (April und Mai 2020) und vier zwischen Juni 2020 und Februar 2021. Die Datenauswertung erfolgte mittels linearer und logistischer Regressionsmodelle.

Ergebnisse: Innerhalb der gesamten Untersuchungsperiode war die Arbeitsbelastung (Care- und Erwerbsarbeit) der Eltern am höchsten während des ersten Lockdowns. Die Arbeitsbelastung war am größten-im Durchschnitt 15 Stunden pro Wochentag-unter Müttern mit Kindern unter sechs Jahren. Während in der Mehrheit der Familien Mütter mehr Care-Arbeit verrichteten, war die Aufteilung in rund einem Drittel ausgeglichen. Care-Arbeit war abhängig von den Erwerbsarbeitsstunden, vor allem für Väter. Gleichzeitig war sie beim selben Erwerbsausmaß höher für Mütter.

Schlussfolgerung: Die COVID-19-bedingten Änderungen in der Erwerbstätigkeit führten $\mathrm{zu}$ einem Anstieg in Arrangements, die davor in Österreich kaum existiert hatten, z. B. Teilzeitarbeit von Vätern. Daher nahmen manche Väter neue Rollen ein, vor allem, wenn sie im Homeoffice arbeiteten (vor allem höher gebildete), nicht erwerbstätig waren (vor allem niedriger gebildete) oder in Teilzeit waren. Es wird diskutiert, ob diese Erfahrungen längerfristig zu egalitäreren Geschlechterrollen führen werden.

Schlagwörter: Österreich; Kinderbetreuung; Hausarbeit; Lockdown; Zeitverwendung 
JFR - Journal of Family Research, 2022, vol. 34, no. 1, pp. 99-132.

doi: $10.20377 /$ jfr-540

Submitted: April 27, 2021

Accepted: November 03, 2021

Published online: November 16, 2021

Caroline Berghammer: https://orcid.org/0000-0003-4955-8729

\section{(c) (1)}

This work is licensed under a Creative Commons Attribution 4.0 International License. 